\title{
Lazaroa
}

\section{Nomenclatural revision and syntaxonomical proposal for wetland peat vegetation in the Valdivian-Magellanian region}

\author{
Javier Amigo ${ }^{1}$, Cristina San Martín ${ }^{2}$, Carlos Ramírez ${ }^{3} \&$ Miguel Álvarez $^{4}$
}

Received: 24 May 2017 / Accepted: 2 October 2017

\begin{abstract}
Although numerous descriptive studies have been published throughout the 20th century on peat communities in the Southern Cone of South America, the nomenclature applied to the different units recognised often fails to take into account the proposals of previous authors. Our aim is to clarify the nomenclature by applying the rules of the ICPN to propose a current syntaxonomy of the class Myrteolo nummulariae-Sphagnetea magellanici. After a bibliographic compilation of possible peatland associations from the part of South America between parallels $40^{\circ}$ and $56^{\circ}$ south, under Temperate and Boreal macroclimates, we have collected around 30 names of phytosociological associations and alliances containing an abundance of homonyms and nomina nuda. Following ICPN standards, we have eliminated duplications and established priority names over others, lectotypified some names and rejected others as nomen ambiguum. We have arranged the floristic groups in the recognised associations in synthetic tables, with some nomina nuda whose characterisation we interpret as doubtful, as a proposed syntaxonomical organisation of the phytosociological class.

The various communities recognised by the different authors who have worked in the territory can be divided into four physiognomic groups: 1. cushion bogs, 2. Sphagnum bogs 3. "montane tundra" bogs and 4. sedge-grass bogs. The syntaxonomic grouping we propose for the 13 associations recognised as nomenclaturally valid can be summarised as follows: a single class, Myrteolo nummulariae-Sphagnetea magellanici, is accepted, with a single order, MyrteoloSphagnetalia, and three alliances: Astelio pumilae-Oreobolion obtusanguli with seven associations (coinciding with type 1), Gaultherio-Sphagnion magellanici with four associations (type 2), and Abrotanello linearifoliae-Bolacion caespitosae with two associations (type 3). We contest the validity of around 22 names of syntaxa of different ranks, while acknowledging that more studies are required, particularly to define and delimit type 4 peatland communities.
\end{abstract}

Keywords: Argentina; Chile; cushion bogs; Sphagnum bogs; phytosociology; Myrteolo-Sphagnetea; peatlands.

\section{[es] Revisión nomenclatural y propuesta sintaxonómica de la vegetación de humedales turbosos de la región Valdiviano-Magallánica}

Resumen. A lo largo del siglo XX se han realizado numerosos estudios descriptivos de comunidades turbosas por el Cono-Sur sudamericano, pero con frecuencia la nomenclatura aplicada a las distintas unidades reconocidas no tenía en cuenta las propuestas de autores anteriores. Nuestro objetivo ha sido clarificar la Nomenclatura aplicando las reglas del CINF para proponer una sintaxonomía de la clase Myrteolo nummulariae-Sphagnetea magellanici. Tras una recopilación bibliográfica de asociaciones de turberas de la parte de Sudamérica comprendida entre los paralelos $40^{\circ}$ y $56^{\circ}$ sur, bajo macroclimas Templado y Boreal, se han reunido alrededor de unos 30 nombres de asociaciones y alianzas fitosociológicas entre los que abundan homonimias y nomina nuda. Aplicando las normas del ICPN se han eliminado duplicidades, establecido nombres prioritarios sobre otros, lectotipificado algunos nombres y rechazado algún otro como nomen ambiguum. Los conjuntos florísticos de las asociaciones reconocidas, junto con algunas nomina nuda cuya caracterización interpretamos como dudosa, se han reunido en tablas sintéticas como propuesta de organización sintaxonómica de la clase fitosociológica.

La diversidad de comunidades que han reconocido los distintos autores que han trabajado en este territorio se puede repartir en 4 grupos fisionómicos: 1. turberas pulvinadas, 2. turberas esfagnosas 3. turberas de "tundra montana" y 4. turberas cipero-graminoides. La agrupación sintaxonómica que proponemos para las 13 asociaciones reconocidas como nomenclaturalmente válidas se resume en: una única clase Myrteolo nummulariae-Sphagnetea magellanici, con un orden único, Myrteolo-Sphagnetalia, y tres alianzas: Astelio pumilae-Oreobolion obtusanguli con 7 asociaciones

\footnotetext{
Laboratory of Botany, Faculty of Farmacy, Universidade de Santiago de Compostela. E-15782 Santiago de Compostela (Spain). Email: javier.amigo.vazquez@usc.es

Earth Sciences and Herbarium Institute, Faculty of Sciences, Universidad Austral de Chile. Valdivia (Chile).

Department of Ecology, Faculty of Biological Sciences, Pontificia Universidad Católica de Chile. Santiago (Chile).

INRES-Vegetationsökologie, Rheinische-Friedrich Wilhelms-Universität, Bonn (Germany).
} 
con nombre válido (coincidentes con el tipo 1), Gaultherio-Sphagnion magellanici con 4 asociaciones (tipo 2), y Abrotanello linearifoliae-Bolacion caespitosae con 2 asociaciones (tipo 3). Se argumenta la invalidez de unos 22 nombres de sintaxones de distinto rango y se reconoce que hacen falta más estudios en especial para definir y delimitar las comunidades de turbera del tipo 4.

Palabras clave: Argentina; Chile; turbera pulvinada; turbera de Sphagnum; fitosociología; Myrteolo-Sphagnetea; turbales.

Nomenclature: Vascular plants: Zuloaga et al. (2009), with the single exception of the consideration of the genus Austroblechnum (Gasper et al., 2016). Bryophyta: The Plant List (Anon., 2013). Lichens: Kirk \& Cooper (2010).

Abbreviations: ICPN: International Code of Phytosociological Nomenclature; MAG: combination of Temperate Magellanian and Antiboreal Magellanian biogeographic provinces; NVald: Northern Valdivian territory $\left(40^{\circ}-45^{\circ}\right.$ South); SVald: Southern Valdivian territory ( $45^{\circ}-47^{\circ}$ South); VP: Valdivian biogeographic province.

\section{Introduction}

The southern part of South America delimited as the Valdivian-Magellanian region, according to the biogeographical proposal of Rivas-Martínez et al. (2011a), is characterized by its temperate (predominantly) or boreal (in the far south) macrobioclimates, as opposed to the precipitation deficit that is characteristic of the Mediterranean macrobioclimate in the adjoining Meso-Chilean-Patagonian region. This biogeographical region largely coincides with the area designated by classic authors as the sub-Antarctic province (Cabrera \& Willink, 1973), the sub-Antarctic subregion (Morrone, 2001) or Maritime Pacific South America (Josse et al., 2003). Some of best bioindicators that give the region its character are particularly the deciduous or perennial Nothofagus forests, and peatlands. These peatlands have traditionally been the focus of interest due to their broad extension in Tierra de Fuego; a large number of studies have been done on the ecosystems in this southern part and in the Magellanian territory due to the logistical facilities in the towns of Ushuaia in Argentina, and Punta Arenas in Chile. However, peatlands of the same type and floristic content extend to parallel $40^{\circ}$ south in the northern part of the Valdivian biogeographical province due to the high levels of rainfall prevailing the length of the Chilean Pacific coast. This area can be permanently classified within the hyperhumid or ultra-hyperhumid ombroclimatic belts, according to the bioclimatic classification of Rivas-Martínez (1993, on line) and Rivas-Martínez et al. (2011b), and interpreted for the Chilean territory in Amigo \& Ramírez (1998) and Luebert \& Pliscoff (2006).

Although there are fewer studies on the peatlands in the Southern Cone than in northern Europe, it is worth mentioning several works that propose detailed classifications of peatland types. The most important of these were taken into account when studying the peatlands in Tierra de Fuego, particularly the work of Bonarelli (1917), and subsequently the classic works of Roivainen (1954) and Auer (1963) which examined in detail the variability in the floristic composition of these ecosystems. These classifications were based mainly on structural and secondarily on floristic aspects, according to the biotypes of the dominant species. These classifications have continued to serve as the basis for more recent models that have set out to cover the whole range of peatlands in South American territory (Blanco \& de la Balze, 2004). There are also reference works from the 20th century with explanations of the ecology and the key parameters affecting peatlands; these include the works of Moore (1983) and Pisano (1983), both of which lack vegetation data such as relevés or complete floristic checklists. Vegetation data, occasionally with floristic relevés, can be found in studies from the same period on specific areas in the Chilean Magellanian territory: the contributions of Pisano (1971, 1972, 1973, 1977) and Dollenz (1980, 1982, 1986) are good examples.

All this information basically focuses on MAG in both Argentina and Chile. However, Oberdorfer (1960) was the first to formulate an integral syntaxonomic proposal: he collected his own relevés from the northern part of the VP (near Valdivia and the island of Chiloé, $40^{\circ}-42^{\circ} \mathrm{S}$ ), together with some listed relevés made by Reiche (1907) in similar areas. He highlighted the common elements between these relevés and others taken in the MAG territory $\left(54^{\circ}-55^{\circ} \mathrm{S}\right)$ based on the work of Roivainen (1954). These formed the basis for the first formal proposals of phytosociological associations and alliances which were collected in one class, Myrteolo-Sphagnetea, intended to describe the vegetation of Chilean 
temperate peatlands. New communities were published shortly after by Ramírez (1968) from the same northern VP area.

Very soon afterwards Knapp (1966) published an outline of how to classify the peatlands in the "sub-Antarctic territory" which included the Chilean region of Magallanes and the Argentinian province of Santa Cruz; he proposed recognizing as many as three phytosociological classes: 1) Astelio-Oreoboletea, for hyper-humid peatlands with an absence of Sphagnum and which can be identified with what we will call cushion bogs, dominated by vascular plant species growing in tight clumps; 2) Rostkovio-Sphagnetea for peatlands with a dominance of Sphagnum spp. (particularly Sphagnum magellanicum) and characterized by a variety of bryophytic species; and 3) Carico-Calthetea, equating to wetlands with permanent waterlogging and incipient peat formation, which can be described by the autochthonous term mallines, containing sedge and grass vegetation. No association was formally published in this work, but the author cited some lists of plants he understood to be characteristic of the classes he proposed.

The works dating from the last third of the 20th century failed to reach any unanimous criteria for interpreting and naming types of peatland; one of the few points of consensus for practitioners of phytosociological methodology was to assume the name of the class Myrteolo-Sphagnetea to include the different communities. Probably the most intensive descriptive work was once again done in MAG, where several associations and alliances were described in an international study conducted from the Pacific to the Atlantic coast (Roig et al., 1985); the proposals deriving from this work rejected various previously published association names, as they were understood to be communities that were not clearly delimited or that "should be analyzed with more information" (Roig et al., op.cit.: 482). In any case, all the names of new syntaxa that were formulated in this work lacked the formal rigour required for the publication, as by then the first International Code of Phytosociological Nomenclature (Barkman et al., 1976) was already in effect.

Subsequent contributions differentiated Magellanian peatlands based on their floristic composition (Schwaar, 1976, 1981), or demonstrated floristic differentiations related to continentality gradients or the biogeochemical features of the peat (Kleinebecker et al., 2007, 2008). New proposals have also been made in regard to peatland communities in the northern VP; that is, in formations in the coastal range from Valdivia to Chiloé Island (San Martín et al., 1999, 2004; Ramírez et al., 2014a). To supplement this work, recent studies have been carried out on the peatlands in the region of Aysén (Teneb et al., 2008; Ramírez et al., 2014b, in press; Rodríguez-Martínez, 2015), a territory of over $100,000 \mathrm{~km}^{2}$, hitherto very little studied and representing the biogeographic intermediary between the northern VP and MAG. These contributions have all served as the basis for a list of peatland plant communities with nearly 30 associations, including a proliferation of nomina nuda or homonyms. This highlights the need for a review of all the names described so far: the purpose is to serve as a guide to anyone wishing to apply phytosociological criteria to studies of peatlands in this territory, and to clarify which associations and alliances have been described previously and must be taken into account before new names are proposed. With all the validly published units we will ultimately propose a final hierarchised syntaxonomical ordination. This is the aim of this work.

\section{Study area}

In addition to delimiting the biogeographic unit (Valdivian-Magellanian region), an ecological specification must be made as to the type of wetlands whose communities we intend to discuss. This can be based on the distinctions expressed by Roig \& Roig (2004), who differentiate mallines, peatlands and mires, according to whether the areas in question are permanently or almost permanently waterlogged, with herbaceous vegetation and abundant organic matter which in certain circumstances may form peat (mallín); ecosystems where peat of various thicknesses has been produced and accumulated (bog or peatland); or areas where peat is being produced and accumulated, with a progressive thickening of the organic deposit (mire). The communities we study grow on peatlands or mires, but this delimitation is not clearly defined by the various authors; although there is an assumed correlation between the English term "peatland" and the Spanish term "turbal"; and between "mire" and "turbera", this distinction is not universally accepted (León, 2012). Thus the name mallín 
may even be used to describe the habitat of a particular community. With regard to the classification made by some Argentinian authors based on the vegetation (Roig \& Roig, op. cit.), we here study the communities framed within the denomination of "peatlands", whereas the other two units, "meadows or mallines" and "peat meadows", include a wide array of formations containing a predominance of grasses and sedges that move progressively further from the concept expressed under the name of the class Myrteolo-Sphagnetea. They will thus only be cited incidentally at the end of this work.

Although topography, and thus hydrogeomorphology, plays a very important role in facilitating the installation of many peatlands (Rodríguez-Martínez, 2015), on a global scale it appears evident that the factor most favouring peat formations is the regional climate regime: these formations are more frequent in areas with a permanently rainy climate (Málvarez et al., 2004). In view of the large rain shadow thrown by the Andean mountains in the Southern Cone, as they contain the perturbations originating in the Southern Pacific (see Figure 1), it is therefore only natural to find a greater extension of peatlands in Chilean territory, particularly in ombrotrophic territories or promoted by rain water. Chilean peatlands have been calculated to cover about 10,470 $\mathrm{km}^{2}$ (Joosten \& Clarke, 2002), although Chilean authors consider this may be an overestimate (Schlatter \& Schlatter, 2004). No detailed estimates are available for Argentinian territory, although there are quantitative data referring only to the peatlands (excluding peat meadows and mallines) present in Tierra de Fuego, which is along with the Falkland Islands, the main Argentinian territory where these ecosystems are found: an area of $500 \mathrm{~km}^{2}$ estimated by Bonarelli (1917).
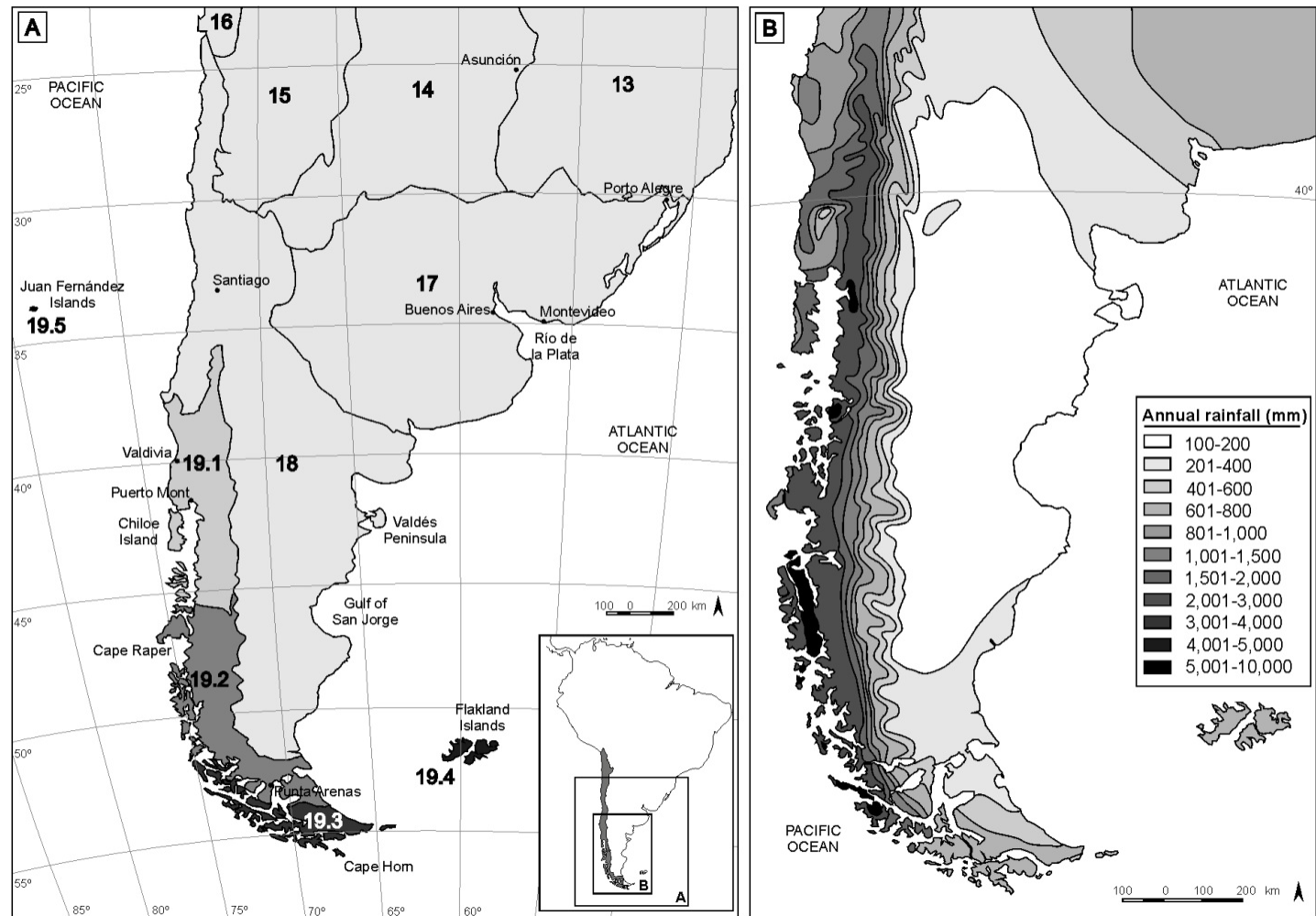

Figure 1. South American Southern Cone. A: Biogeographical regions according to Rivas-Martínez et al. (2011a) classification: 13: Brazilian-Paranensean; 14: Chocoan; 15: Tropical South Andean; 16: Hyperdesertic Tropical Pacific; 17: Pampean; 18: Middle Chilean-Patagonian; 19: Valdivian-Magellanian. Peatlands involved in this study belong to units 19.1, 19.2 and 19.3. B) Maximum annual rainfall (from Málvarez et al., 2004). 
Biogeographical territories corresponding to the Valdivian-Magellanian region considered in this study can be delimited as follows:

The VP extends from parallel $37^{\circ}-38^{\circ}$ to $47^{\circ}-48^{\circ}$ south, and $90 \%$ of its area corresponds to Chile vs. $10 \%$ to Argentina. The greatest presence of peatlands in this province is associated to hyperoceanic areas, which continue to be abundant throughout the islands and the westernmost part of the fjords that indent the coast through to Cape Raper. However, due to their inaccessibility we have no data on these areas. Such hyperoceanic areas with important data on peatland vegetation are the coastal mountain range between the cities of Valdivia and Osorno, Chiloé Island and Los Chonos Islands $\left(40^{\circ}-45^{\circ}\right.$ South).

Only recently, studies on peatlands in the region of Aysén in environments hyperhumid-humid have been done. In the Results and Discussion section, data from territories between $40^{\circ}-45^{\circ}$ are called 'Northern Valdivian (NVald)', whereas those in the band between $45^{\circ}-47^{\circ}$ are called southern Valdivian (SVald).

In addition to the VP and the chorological province of Juan Fernández, which here is completely discarded due to the total absence of peatlands, the classification of Rivas-Martínez et al. (2011a) distributes the remainder of the biogeographical region into three provinces: Temperate Magellanian, Antiboreal Magellanian and the Falkland Islands. With the exception of the data from these islands, the others are not easy to assign to one or another province, as Tierra de Fuego is distributed between the first and second. We therefore often refer to data from these provinces as simply "Magellanian" (abbreviated to MAG) in comparison with the vegetation from the VP.

\section{Material \& Methods}

We have examined the current and past bibliography containing floristic information on possible peatland and bog communities. The authors' proposals include numerous cases of overlapping floristic compositions which have given rise to a proliferation of names to describe combinations of species that could reasonably be interpreted as the same association, expressed with different aspects. Before determining whether ' $\mathrm{X}$ ' floristic composition expresses the reality of the association better than another ' $Z$ ' combination, we de- cided to select the combinations whose publication has been validated according to the criteria stipulated in the third edition of the International Code of Phytosociological Nomenclature (Weber et al., 2000; Izco \& Del Arco, 2003).

The application of the ICPN rules, and of article $29 \mathrm{~b}$ in particular, have also required the modification of some association names that were illegitimate. With the set of nomenclaturally accepted associations, and based on the similarities between their floristic contents, we propose a syntaxonomical ordination of the communities they represent.

\section{Results \& Discussion}

We describe the nomenclatural valid syntaxa in decreasing order of ordination in a syntaxonomical checklist.

\section{Acceptable names of syntaxa}

Starting with the upper ranks, the full name is accepted for a single phytosociological class: Myrteolo nummulariae-Sphagnetea magellanici Oberdorfer 1960. Although Oberdorfer (1960) only discussed "Myrteolo-Sphagnetea" in his syntaxonomical checklist, there appears to be no doubt after the author's explanations that the name used to describe Sphagnum should be $S$. magellanicum. The name corresponding to the genus Myrteola may be debatable, as Oberdorfer (op.cit.) repeatedly cited "Myrteola damaeonchii Berg". As noted a few years later by Ramírez (1968), this was what was known by Chilean authors as M. barneoudii Berg, and by others as M. nummularia (Poir.) Berg var. barneoudii (Berg) Kausel. In a detailed monograph on Chilean myrtles, Landrum (1988) clarified that not even the varietal rank was worth to distinguish and collected all the previously published names under the single binomial of Myrteola nummularia (Poiret) Berg; this is the criterion we follow here.

Other subsequent proposals can be considered. Knapp (1966) interpreted the recognition of two classes: one Astelio-Oreoboletea for the peatlands in hyperhumid territory identifiable as cushion bogs, and a Rostkovio-Sphagnetea for acidophilus Sphagnum bogs. To accept this separation at the level of the highest syntaxonomical rank it is necessary to recognise the priority of the alliance Astelio-Oreobolion 
Oberdorfer 1960 (the priority is not recognised by Knapp op. cit.), before using it as the nomenclatural type for Astelio-Oreoboletalia and Astelio-Oreoboletea. As will be explained below, there are enough transitional situations between these two major peatland types (cushion and Sphagnum), with floristic convergence between both types, to rule out the option of two different classes. In addition, if the proposed class Astelio-Oreoboletea is to be accepted, the other non-cushion bogs cannot be integrated in a syntaxon that bears the name of Rostkovio-Sphagnetea, as this group of communities would have priority eligibility to the name Myrteolo-Sphagnetea, making Rostkovio-Sphagnetea a younger homonym and therefore invalid. The option of a class Rostkovietea raised by Roig et al. (1985) is inappropriate in our view: in addition to being invalid nomenclaturally (as per article 5 of the ICPN), we understand this proposal to have little floristic support as the three associations attributed to it by its authors appear to be a mixture of elements from bryophytic peatlands with characteristic species from the class Littorelletea australis of temporary lakes (see Deil et al., 2011).

The nomenclatural type of the single class is the order Myrteolo nummulariae-Sphagnetalia magellanici Oberdorfer 1960, the sole order when the name of the class was first published. As described below, there have been some proposals, also invalid (Roig et al., 1985), to include another different order; as outlined in the Conclusions section, our opinion is to recognise a single order.

The first point to consider in distinguishing alliances within this order is the two most widely verified models of peatlands that have been recognised by all authors studying peatland ecosystems in the Southern Cone and which they have sought to reflect in their classifications: Sphagnum bogs and cushion bogs. This can be interpreted as underlying the two alliances proposed by Oberdorfer (op. cit.), who sought a parallel between his personal observations in the NVald territory and the studies of Roivainen (1954) in MAG. Another classic author who studied MAG territory in depth coined the term "Magellanian tundra" as one of the five major "biotic provinces" that can be recognised in MAG (Pisano, 1977), distinguishing within this category a cushion tundra and a Sphagnum tundra. The recognition of these ecosystems studied in Argentinian territory is open to a similar interpretation, as Roig (1998) collected only two alliances for his syntaxonomical checklist for Patagonia: one Sphagnion magellanici for Sphagnum bog communities; and the other Donation fascicularis for cushion bog communities, although both syntaxonomical names were ultimately invalid, as we will explain below.

Without venturing any proposals for communities, Kleinebecker et al. (2007) also coincided in recognising this dual model (cushion/ Sphagnum) along a west-east transect in MAG, which they clearly related to a continentality gradient and a decline in precipitation. Although this simplification excludes other possible physiognomic types worthy of consideration such as grassy bogs (Pisano, op. cit.) or what is known as "montane tundra" in MAG (Roig et al., 1985), it is sufficient to start by recognising associations that have been described since the mid-20th century to the present day.

\section{Cushion bogs}

This is a particular group of communities as they represent a physiognomic type that is endemic in the southern hemisphere, occurring in the Valdivian-Magellanian region and also in Tasmania and New Zealand, with which they share genera but differ in their vicariant species (Godley, 1960; Wardle, 1991; Wardle et al., 2001; Ramírez et al., 2014a). Their particularity is the absolute dominance of vascular plants which build dense cushions, and a very low (in terms of biomass) participation of briophytes. Cushion bogs are very common in the Magellanian tundra (Schmithüsen, 1953; Pisano, 1977, 1983) located around the Strait of Magellan in the coastal islands exposed to strong winds and abundant precipitation. Along the sinuous southwestern coast of Chile they extend northwards to the Chonos Archipelago, at $44^{\circ} \mathrm{S}$ (Álvarez et al., 2010); and these communities are found even further northwards at higher altitudes, such as at $600 \mathrm{~m}$ a.s.l. on Chiloé Island at $42^{\circ} \mathrm{S}$ (Ruthsatz \& Villagrán, 1991) and $1000 \mathrm{~m}$ a.s.l. in the Cordillera Pelada at $40^{\circ} \mathrm{S}$ (Ramírez, 1968; San Martín et al., 1999). It should be noted that the northernmost cushion bog communities were used as the reference for the earliest phytosociological descriptions due to their accessibility, and the names derived from those studies have priority according to the ICPN. 


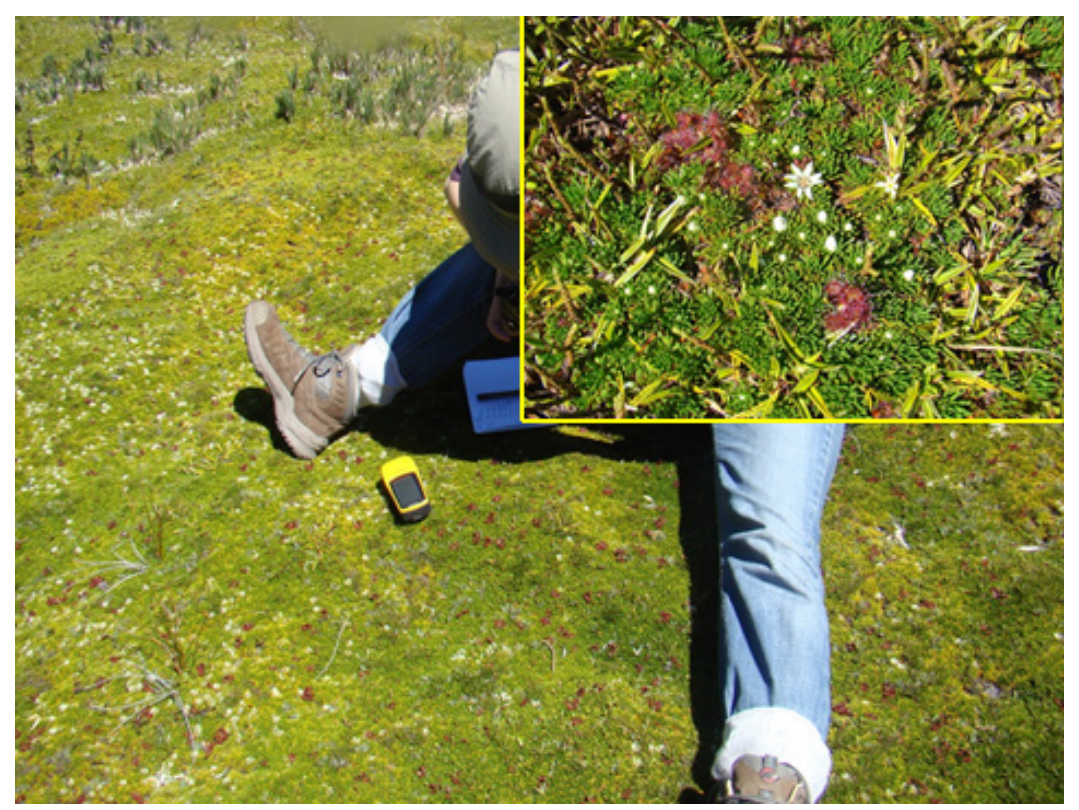

Figure 2. Typical Donatia-cushion-bog which supports the weight of the botanist (doing his relevé) without deforming it. In the box we can see Donatia fascicularis, Astelia pumila and Drosera uniflora in dense folder. Chiloé Island (Los Lagos, Chile. $42^{\circ} \mathrm{S}$ ).

Table 1. Synthetic table of Astelio-Oreobolion and Gaultherio-Sphagnion.

Floristic comparative among the recognized peatland associations included in Group 1 and 2. In addition, grey central columns show the floristic composition of three communities described as related to group 2 but of uncertain syntaxonomic position (see text). The so-called "Sphagnetum magellanici" is also a nomen dubium.

\begin{tabular}{|c|c|c|c|c|c|c|c|c|c|c|c|c|c|c|c|}
\hline Association Code & 1.1 .1 & 1.1 .2 & 1.2 & 1.3 & 1.4 & 1.5 & 1.6 & 1.7 & Sph & $D o S$ & Mar & 2.1 & 2.2 & 2.3 & 2.4 \\
\hline N. of relevés & 3 & 3 & 5 & 4 & 24 & 5 & 7 & 10 & 1 & 6 & 4 & 4 & 25 & 7 & 8 \\
\hline Relevé N. & 1 & 2 & 3 & 4 & 5 & 6 & 7 & 8 & 9 & 10 & 11 & 12 & 13 & 14 & 15 \\
\hline Differentials of associations & & & & & & & & & & & & & & & \\
\hline Schoenus rhynchosporoides & 1 & 1 & II & . & . & . & . & . & . & . & . & . & . & . & . \\
\hline Schizaea fistulosa & 2 & 2 & . & 1 & . & . & III & . & . & . & . & . & . & . & . \\
\hline Gaultheria caespitosa & 1 & . & . & 1 & . & . & . & . & . & . & . & 3 & . & . & . \\
\hline Pinguicula chilensis & . & 1 & . & . & . & . & . & . & . & . & . & . & . & . & . \\
\hline Gentianella magellanica & . & . & $\mathrm{V}$ & . & . & . & . & . & . & . & . & . & . & . & . \\
\hline Chusquea montana & . & . & III & 4 & IV & . & . & . & . & . & . & 1 & . & . & . \\
\hline Racomitrium lanuginosum & . & . & $\mathrm{V}$ & 1 & I & . & . & . & . & II & . & . & . & . & . \\
\hline Marsippospermum philippi & . & . & . & 4 & I & . & . & . & . & . & . & . & . & . & . \\
\hline Baccharis patagonica & . & . & . & . & III & . & 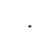 & . & . & 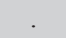 & 1 & . & . & . & I \\
\hline Schoenus antarcticus & . & . & . & . & $\mathrm{V}$ & . & $\mathrm{V}$ & . & 1 & $\mathrm{~V}$ & . & . & . & . & . \\
\hline Lepidothamnus fonkii & . & 1 & . & . & . & $\mathrm{V}$ & II & . & . & $\mathrm{V}$ & 1 & . & . & . & I \\
\hline Austrolycopodium confertum & . & . & . & . & . & II & . & . & . & I & . & . & . & . & . \\
\hline Senecio smithii & . & . & . & . & . & II & . & . & . & . & . & . & . & . & . \\
\hline Schoenus andinus & . & . & . & . & . & IV & . & . & 1 & . & . & . & . & . & . \\
\hline Abrotanella linearifolia & . & . & . & . & . & . & III & 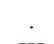 & . & & . & . & . & . & . \\
\hline Gunnera lobata & . & . & . & . & . & . & II & III & 1 & III & 2 & . & . & . & . \\
\hline Caltha dioneifolia & . & . & . & . & . & . & IV & III & 1 & . & . & . & . & . & . \\
\hline Dicranoloma hariotii & . & . & . & . & . & . & . & $\mathrm{V}$ & . & . & . & . & I & III & . \\
\hline Drapetes muscosus & . & . & . & . & . & . & . & II & . & . & . & . & I & III & . \\
\hline Chorisodontium aciphyllum & . & . & 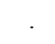 & . & . & . & . & IV & . & . & . & . & II & I & . \\
\hline Polytrichum alpestre & . & . &  & . & . & . & . & 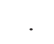 & . & . & . & . & III & . & . \\
\hline Juncus scheuchzerioides & . & . & . & . & . & . & . & 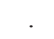 & + &  & . & . & + & . & . \\
\hline Carex camptoglochin & & & & & - & & & II & 1 & & & 1 & . & & II \\
\hline
\end{tabular}




\begin{tabular}{|c|c|c|c|c|c|c|c|c|c|c|c|c|c|c|c|}
\hline \multicolumn{16}{|l|}{ Gaultherio-Sphagnion magellanici } \\
\hline Sphagnum magellanicum & 2 & 2 & 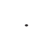 & . & . & . & . & . & 5 & IV & 1 & 4 & $\mathrm{~V}$ & $\mathrm{~V}$ & $\mathrm{~V}$ \\
\hline Carex magellanica & 3 & . & . & . & . & . & . & I & 2 & I & 2 & 2 & II & III & III \\
\hline Nanodea muscosa & . & . & . & . & . & . & . & II & 2 & I & 1 & . & III & $\mathrm{V}$ & IV \\
\hline Sphagnum fimbriatum & . & . & . & . & . & . & . & . & 1 & . & 1 & . & II & I & . \\
\hline Rostkovia magellanica & . & . & . & . & . & . & . & . & 1 & . & . & . & III & $\mathrm{I}$ & . \\
\hline Carex canescens & . & . & . & . & . & . & . & . & . & . & . & . & + & . & I \\
\hline \multicolumn{16}{|l|}{ Astelio-Oreobolion obtusanguli } \\
\hline Oreobolus obtusangulus & 3 & 3 & $\mathrm{~V}$ & 2 &. & . & IV & $\mathrm{V}$ & 1 & $\mathrm{~V}$ & 2 & . & . & r. & . \\
\hline Astelia pumila & . & 3 & $\mathrm{~V}$ & 4 & IV & . & $\mathrm{V}$ & IV & 2 & $\mathrm{~V}$ & . & 1 & . & I & . \\
\hline Donatia fascicularis & . & 3 & $\mathrm{~V}$ & . & IV & $\mathrm{V}$ & $\mathrm{V}$ & IV & 2 & $\mathrm{~V}$ & . & . & . & . & . \\
\hline Tapeinia pumila & . & 1 & III & . & I & . & IV & III & 2 & . & . & . & . & . & . \\
\hline Gaimardia australis & . & 1 & $\mathrm{~V}$ & 1 & + & . & IV & III & 1 & V & . & . & . & . & . \\
\hline Tribeles australis & . & 1 & . & 1 & . & . & . & IV & . & . & . & . & . & . & . \\
\hline \multicolumn{16}{|l|}{ Myrteolo-Sphagnetea magellanici } \\
\hline Myrteola nummularia & 2 & 3 & $\mathrm{~V}$ & 4 & I & . & IV & $\mathrm{V}$ & 2 & II & 4 & 4 & . & IV & IV \\
\hline Drosera uniflora & . & 3 & $\mathrm{~V}$ & . & II & IV & $\mathrm{V}$ & II & 2 & $\mathrm{~V}$ & . & 3 & . & $\mathrm{I}$ & . \\
\hline Gaultheria pumila & . & . & . & 3 & II & III & I & II & 3 & IV & 1 & . & IV & III & IV \\
\hline Acaena pumila & . & 1 & . & 1 & . & . & III & IV & 1 & $\mathrm{~V}$ & 2 & . & . & IV & . \\
\hline Tetroncium magellanicum & . & 2 & . & 1 & . & . & I & III & 2 & $\mathrm{~V}$ & 2 & . & I & $\mathrm{V}$ & II \\
\hline Marsippospermum grandiflorum & . & 1 & . & . & . & . & IV & II & 2 & I & 4 & . & I & II & IV \\
\hline Carpha schoenoides & . & 3 & . & 1 & . & . & . & III & 1 & I & 2 & . & . & II & . \\
\hline Gaultheria antarctica & . & . & . & . & . & II & . & $\mathrm{V}$ & . & . & . & 1 & . & III & \\
\hline Caltha appendiculata & . & . & . & . & . & . & II & $\mathrm{V}$ & 2 & $\mathrm{~V}$ & 2 & . & . & IV & I \\
\hline Pinguicula antarctica & . & 1 & . & 1 & . & . & . & . & . & I & . & . & . & . & . \\
\hline Perezia lactucoides & . & 1 & . & 1 & . & . & . & . & 2 & . & 2 & . & . & . & II \\
\hline Perezia magellanica & . & . & . & . & . & . & . & I & + & . & . & . & . & I & I \\
\hline \multicolumn{16}{|l|}{ Wintero-Nothofagetea species } \\
\hline Nothofagus antarctica & 1 & . & IV & 4 & + & 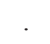 & $\mathrm{V}$ & I & 2 & IV & 1 & . & III & IV & $\mathrm{I}$ \\
\hline Nothofagus betuloides & . & . & . & . & II & IV & III & I & . & $\mathrm{V}$ & 2 & . & . & . & II \\
\hline Austroblechnum penna-marina & 2 & . & . & 3 & . & . & . & . & . & I & 3 & 1 & . & . & IV \\
\hline Pilgerodendron uviferum & . & . & . & 1 & + & $\mathrm{V}$ & . & . & . & $\mathrm{V}$ & 1 & . & . & . & . \\
\hline Berberis serrato-dentata & . & . & . & 2 & I & . & . & . & . & . & . & . & . & . & . \\
\hline Drimys winteri & . & . & . & . & + & . & . & I & + & . & . & . & . & . & . \\
\hline Lebetanthus myrsinites & . & . & . & . & . & . & IV & . & . & . & . & . & . & . & I \\
\hline Philesia magellanica & . & . & . & . & . & I & I & . & . & I & 1 & . & . & . & . \\
\hline \multicolumn{16}{|l|}{ Companion species } \\
\hline Empetrum rubrum & 1 & 1 & & . & . & . & . & II & 3 & I & 2 & . & IV & II & IV \\
\hline Cladonia confusa & . & . & IV & 2 & . & . & . & . & . & . & . & . & . & . & . \\
\hline Gaultheria mucronata & . & . & . & . & . & I & . & . & 1 & II & 3 & . & . & . & II \\
\hline Cortaderia pilosa & . & . & . & . & . & . & II & . & 1 & . & 1 & . & . & . & . \\
\hline Thamnolia vermicularis & . & . & . & . & . & . & IV & . & . & II & . & . & . & . & . \\
\hline Gunnera magellanica & . & . & . & . & . & . & II & . & 2 & . & 4 & . & . & I & I \\
\hline Cladonia vicaria & . & . & . & . & . & . & . & III & . & . & . & . & II & $\mathrm{I}$ & . \\
\hline Chiliotrichum diffusum & 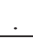 & . & & . & . & & . & $\mathrm{I}$ & 1 & . & 1 & . & $\mathrm{I}$ & III & $\mathrm{I}$ \\
\hline
\end{tabular}

Other species: Cladonia pycnoclada 2, Sticherus quadripartitus, Dicranoloma sp. and Campylopus sp. 1, in 1; Baccharis magellanica 4, Senecio acanthifolius and Sphagnum sp. 3, Fitzroya cupressoides 1, in 4; Nothofagus nitida and Olsynium junceum + in 5; Lomatia ferruginea III in 6; Tepualia stipularis II in 7; Festuca thermarum, Cladonia laevigata, Chorisodontium magellanicum, Dicranoloma robustum and Sphagnum falcatulum I in 8; another 17 species: shrubby (2 Berberis), grass-sedge type (2 Carex, 1 Uncinia, 2 Festuca) and chamaephytics (2 Azorella, 2 Bolax) in 9; Cladonia pycnoclada and Dicranoloma billardierei II, Racomitrium wilii V, in 10;. Juncus cyperoides 1 in 12; Chorisodontium leucopterum and Juncus balticus I, Uncinia tenuis and Hymenophyllum peltatum II, Luzuriaga marginata IV, in 15.

Relevé source: 1: Schoeno rhynchosporoides-Oreoboletum obtusanguli. Oberdorfer 1960, Tb. 43B; 2: 'Schoeno rhynchosporoidesOreoboletum obtusanguli' Reiche in Oberdorfer 1960, Tb. 43B; 3: Drosero uniflorae-Donatietum fascicularis. Ramírez 1968 , Tb. 1; 4: Astelio pumilae-Marsippospermetum philippi Ramírez 1968, Tb. 2; 5: Chusqueo montanae-Schoenetum antarctici. Ramírez et al. 2014b, Tb. 6; 6: Schoeno andini-Lepidothamnetum fonkii Ramírez et al. 2014, Tb. VI; 7: Donatio fascicularis-Schoenetum antarctici Roig et al. 1985, Tb. 48, gr. 72 (sub Donatietum fascicularis); 8: Caltho-Oreoboletum obtusanguli Oberdorfer 1960, Tb. 44, col.'e'; 9: Sphagnetum magellanici nomen illegitimum et dubium Pisano 1977, Tb. XXI; 10: Donatio-Sphagnetum magellanici nomen nudum. Roig et al. 1985: Tb. 48, gr. 74; 11: Marsippospermetum grandiflori nomen nudum. Roig et al. 1985, Tb. 48, gr. 76; 12: Gaultherio-Sphagnetum magellanici. Oberdorfer 1960, Tb. 43; 13: Polytricho alpestris-Sphagnetum. Oberdorfer 1960, Tb. 44, col.'a'; 14: Oberdorfer 1960, Tb. 44, col.'b'; 15: Nanodeo muscosae-Sphagnetum magellanici. Roig et al. 1985, Tb. 48, gr. 75 (sub Carico-Sphagnetum). 
1.1. Schoeno rhynchosporoides-Oreoboletum obtusanguli Oberdorfer 1960

Lectotypus hoc loco: Oberdorfer (1960), pag. 160, Tab. 43, rel. 282a.

This is probably the oldest association proposed for NVald, and is supported on six clearly heterogeneous relevés, half of which were collected by Oberdorfer (1960), and the rest cited from Reiche (1907) in several western localities in NVald, though most are from Chiloé Island. Table 1 shows both halves separately to highlight their differences, since they in fact indicate two distinct communities with only six species in common. The half of SchoenoOreoboletum obtained from Oberdorfer (rel. 1 in Table 1) has a low number of species, whereas the other half obtained from Reiche (rel. 2 in Table 1) has many more species, especially the most representative in Group 1. The main formal problem with the last three relevés (Reiche's relevés) is that they contain only lists of species occurrence, with no information on their abundance, so only one relevé from the first three can be used as a type for this association, even accepting that they reflect a floristically poor situation.

In spite of the different biotypes of the two species, the association name does not need to be inverted (as "Oreobolo-Schoenetum"), in a hypothetical application of Article $29 \mathrm{~b}$ of the ICPN. Although the sedge Sch. rhynchosporoides is taller than Oreobolus obtusangulus and most of the species in the dense mat, the cover index assigned by Oberdorfer in a single relevé with the presence of this sedge was 1.2.

\subsection{Drosero uniflorae-Donatietum}

fascicularis Ramírez 1968 nom. inv.

propos.

Holotypus: Ramírez (1968), pag. 96, Tab. 1, rel. 3 [sub Donatia fascicularis-Drosera uniflora Assoziation]

This association was published with five relevés collected in the Cordillera Pelada $\left(40^{\circ} \mathrm{S}\right)$ in a typical hyperhumid cushion bog dominated by Donatia fascicularis with the addition of Drosera uniflora, Gaimardia australis and Tapeinia pumila. There is also a presence of Oreobolus obtusangulus and Astelia pumila, though with less abundance than in association 1.1 but with a higher number of species. Two species must be highlighted for their biogeographical significance in relation to NVald: Schoenus rhynchosporoides and Chusquea montana, the latter a typical taxon of bogs usually cited as Chusquea nigricans. San Martín et al. (1999) established the lectotype for this association and inverted the name, since Donatia fascicularis always acts as the dominant species and produces the highest biomass, and D. uniflora is not located in a high stratum with respect to Donatia; the authors of this article hereby submit a proposal to formalise the nomenclatural inversion.

A recent proposal concerned Donatio fascicularis-Oreoboletum obtusangulae (sic), for cushion bogs from the coastal range on Chiloé Island at $42^{\circ} \mathrm{S}$ (Ramírez et al., 2014b). We consider it has no major floristic differences with Drosero-Donatietum fascicularis but represents a facies with a dominance of Oreobolus obtusangulus, and is otherwise completely similar to 1.2 , including the presence of the bryophyte Racomitrium lanuginosum. Therefore the name "Donatio-Oreoboletum" must be interpreted merely as a synonym.

\subsection{Astelio pumilae-Marsippospermetum philippi Ramírez 1968}

Holotypus: Ramírez(1968),pag.98, Tab.2,rel.2 [subAsteliapumila-Marsippospermumphilippi Assoziation]

This association was described by Ramírez (1968) with relevés collected in the Cordillera Pelada, and was further typified by San Martín et al. (1999). The main differences with the previous communities are the dominance of Astelia pumila, and the greater importance of the sedge Marsippospermum philippi and the dwarf bamboo Chusquea montana. Both these species support the discrimination from other communities dominated by Astelia pumila but described in southern territories. The higher cover of Astelia pumila can be correlated with initial succession stages in the vegetation dynamic during the regeneration of Donatia fascicularis bogs, as suggested by Ruthsatz \& Villagrán (1991) on the basis of palynological studies; it may also be related to the substrate, which is a mixture of peat and sand (San Martín et al., 1999), possibly explaining the participation of some woody species such as 
Baccharis magellanica, Nothofagus antarctica and Berberis serrato-dentata.

Although the physiognomy of this community usually takes the form of dense cushions of Astelia pumila, the erect position of Marsippospermum philippi, Chusquea montana and Nothofagus antarctica can be considered to belong to a higher layer growing to between 20 and $50 \mathrm{~cm}$ above the mat of Astelia pumila. As one of the species has a sufficiently high average cover to be considered a "determining stratum", in the sense of Article $29 \mathrm{~b}$ of the ICPN (Chusquea montana with index "3"), and Marsippospermum philippi belongs to this stratum of the community, the name Astelio-Marsippospermetum is nomenclaturally admissible, but not its inversion "Marsippospermo-Astelietum pumilae", as proposed by San Martín et al. (1999).

\subsection{Chusqueo montanae-Schoenetum} antarctici Ramírez et al. 2014

Holotypus: Ramírez et al. (2014b), pag. 28, Table 6, rel. 12.

This association was also described for Chiloé Island $\left(42^{\circ} \mathrm{S}\right)$. The community is similar to 1.3 , but reflects a transition of cushion bogs to more xeric conditions where some woody species such as Baccharis patagonica, Nothofagus betuloides and Pilgerodendron uviferum are integrated in a dense carpet dominated by Donatia fascicularis. The drier conditions are also evidenced by the occurrence of sedges and grasses, represented by Chusquea montana and Schoenus antarcticus. Baccharis patagonica is a differential species with 1.3 (although Baccharis magellanica is also present under similar conditions according to Ruthsatz \& Villagrán, 1991), with Donatia fascicularis, Tapeinia pumila, Gaultheria pumila and Schoenus antarcticus. The presence of sedges and grasses give this community a slightly similar physiognomy to the bog formations discussed below in Group 4.

\subsection{Schoeno andini-Lepidothamnetum fonkii} Ramírez et al. 2014

Holotypus: Ramírez et al. (2014a), pag. 248, Table VI, rel. 21.

This association was described for territories in SVald, around $46^{\circ} \mathrm{S}$. Although the name is taken from a sedge and the peculiar dwarf cypress, it is a typical cushion bog dominated by Donatia fascicularis, with the addition of Drosera unifolia,
Gaultheria pumila and Astelia pumila. As stated by Ramírez et al. (2014a), these communities are located in "higher and inaccessible locations, over plains". These ombrogenic bogs occur in the hyperhumid ombroclimate and grow on a thin peat layer, with some intrusions of shrubs depending on the interannual seasonality. The relevés therefore also contain some woody species such as Pilgerodendron uviferum, Gaultheria mucronata and even Nothofagus betuloides. This community is differentiated from other Donatia-dominated communities by the absence of Tapeinia pumila, Gaimardia australis, Oreobolus obtusangulus and Myrteola nummularia. Senecio smithii, Schoenus andinus and Austrolycopodium confertum can be considered as differential species for this association.

\subsection{Donatio fascicularis-Schoenetum antarctici ass. nova hoc loco}

Holotypus: Roig, Dollenz \& Méndez (1985), Tab. 48, Group 72, rel. 125 [sub Donatietum fascicularis nomen nudum]

We chose to consider this community type as an association of cushion bogs dominated by Donatia fascicularis from MAG, which unfortunately received an invalid name. This association is supported by seven relevés collected on Piazzi Island (51 $41^{\circ}$ 'S) by Roig et al. (op. cit.). Its floristic composition is similar to 1.2 and even to 1.4, but the main differences concern its biogeographical position with respect this two associations: 1.2 and 1.4 are associations from the NVald territory, whereas Donatio-Schoenetum antarctici is from the MAG territory. Thus 1.6 has an occurrence of Abrotanella linearifolia, Gunnera lobata or Caltha dioneifolia that never arrive to NVald territory. Conversely Chusquea montana and Schoenus rhynchosporoides are species from 1.2 or 1.4 but absent in DonatioSchoenetum antarctici.

\subsection{Caltho-Oreoboletum obtusanguli Oberd.} 1960

Holotypus: does not exist

This association is similar to 1.6 , derived from the samples taken by Roivainen (1954) in MAG corresponding to the western part of Tierra del Fuego, in extremely oceanic areas in contact with Nothofagus betuloides forests $\left(54^{\circ} \mathrm{S}\right.$, Antiboreal Magellanian province). Nevertheless, its floristic content was compiled by Oberdorfer (1960) who summa- 
rised ten relevés from Roivainen (Oberdorfer, 1960, page 161, Table 44, column 'e'). The last column was considered as sufficient diagnosis (Art. 7 ICPN), but not sufficient for a typus. Nor do we know of any later work using this name to refer to inventories of similar communities in MAG, so there is no possibility of seeking a neotype.

In addition to Oreobolus obtusangulus, the species selected by Oberdorfer (op. cit.) to give the name to the association, Roivainen's descriptions (op. cit.) show that these are carpets of vascular plants in which Astelia pumila, Tapeinia pumila and Gaimardia australis are also characteristic species of this association. Table 1 reveals differential species between these Caltho-Oreoboletum in the MAG territory and 1.1, 1.2 and 1.3 in the VP territories. Caltho-Oreoboletum has more species in common with 1.6 due to its biogeographical similarity; but it can be differentiated due to the presence in 1.6 of Abrotanella linearifolia, Schizaea fistulosa, Lepidothamnus fonkii and Schoenus antarcticus which are absent from 1.7; while 1.7 has an occurrence of Tribeles australis, Carpha schoenoides and Nanodea muscosa, which are absent from 1.6 and very rare in associations of NVald.

Two clarifications are required in regard to the floristic content compiled by Oberdorfer (1960): 1) When Oberdorfer chose the asso ciation name he did not select either of the two Caltha species occurring in this community, namely Caltha appendiculata and C. dioneifolia; if publication had occurred after 1979, this proposed name would be invalid (Art. 3g ICPN). If future relevés are published citing this community for the selection of a neotype, Caltha dioneifolia would be the ideal candidate due to the precision of the name, since the distribution of this taxon is limited to the MAG and SVald territory, and does not reach as far as NVald (Ruiz, 2001). Meanwhile, Oberdorfer's lack of definition leaves the name so far as: Caltho-Oreoboletum obtusanguli. 2) In column 'e' of Table 44 assigned to the CalthoOreoboletum association, Oberdorfer (op. cit.) cited the constant presence of Gaultheria caespitosa Poepp. \& Endl., although the only species considered in Roivainen's relevés (op. cit.) was Gaultheria serpyllifolia (Lam.) Skottsb., currently accepted as synonymous with $G$. antarctica Hook $\mathrm{f}$. In addition to a possible misidentification (see below in association 2.1), current knowledge of the distribution of both species indicates that $G$. caespitosa has its southern boundary in the NVald territory, while $G$. antarctica extends from NVald to MAG (Zuloaga et al., 2009; Teillier \& Escobar, 2013). The floristic information provided by Oberdorfer in column ' $\mathrm{e}$ ' should therefore be corrected, and the presence of G. caespitosa replaced with $G$. antarctica.

\subsection{Other proposals related to Group 1}

Additional names have been proposed for syntaxa related to cushion bog vegetation. For instance, Roig et al. (1985) proposed Schoeno antarcticae-Nothofagetum antarcticae for MAG and indicated it as similar to "Donatietum fascicularis" (1.6), both described in the same publication, and classified them in the alliance Donation fascicularis nomen nudum. In addition to being an invalid name (see Table 3), the community known as SchoenoNothofagetum antarcticae is excluded from Table I as it lacks all the vascular cushionbog plants, with the sole exception of Astelia pumila, which appeared in two of the three relevés assigned to the association. In contrast, Marsippospermum grandiflorum and Schnoenus antarcticus are constant, together with Cortaderia pilosa (in two relevés). This perhaps reflects more a different physiognomic type, namely fen grasslands (Roig et al., op. cit.: 482), characterised by a different accumulation of organic matter which allows the establishment of Nothofagus antarctica and rush species that are more characteristic of wet grasslands than the Donatio-Schoenetum antarctici. We prefer to consider this type of communities in the category of sedge and grass fens discussed below in Group 4.

Bogs of dense cushions including Astelia pumila as the dominant species have been studied in Cape Horn and the Falkland Islands by Martínez-Carretero (2004). More recent contributions have come from the Aysén region (SVald), where several stands of Donatia fascicularis have been studied as well. However, in both cases, the authors did not propose any specific syntaxonomic name.

\section{Associations of Sphagnum bogs and mires}

The next major group of communities is usually included under the term Magellanian tundra. Here there is an absolute dominance of bryophytes, 
especially of the genus Sphagnum and particularly of Sphagnum magellanicum, which can be clearly recognized by its reddish colour and constitutes an entire geobotanical symbol of the Magellanian landscape and Tierra del Fuego. In contrast with ombrotrophic cushion bogs, Sphagnum bogs are mainly minerotrophic and usually occur "in valley bottoms, along streams or stagnant wetlands, or by filling depressions or buckets in contact with forests" (Roig \& Roig, 2004). Though there is a typical discrimination between cushion bogs with a hyperhumid ombroclimate and Sphagnum bogs with a humid-subhumid and even dry ombroclimate (Pisano, 1977; Roig et al., 1985), there is a continuous gradient between both types, as noted by Kleinebecker et al. (2007, 2010), who identified intermediate stages along a westeast gradient which they called mixed cushionSphagnum bogs. Even within purely Sphagnum bogs, several physiognomic types have been distinguished depending on the nutrient supply, the height of the Sphagnum stands, the water table and its fluctuations, and so on. One of the most thorough investigators of biodiversity in these Sphagnum bogs, focused mainly on Tierra de Fuego (Auer, 1965), identified three different types: progressive Sphagnum bogs, (ombrogenic) Sphagnum bogs, and regressive Sphagnum bogs, which were also related to a gradient of higher to lower precipitation respectively (see also Roig, 2004). The micro-topography of the bogs is also important, and results in the formation of hummocks alternating with hollows that fill with water soaking into the ground. All these variables allow or restrict the establishment of species and produce patchy patterns in the distribution of plant communities.

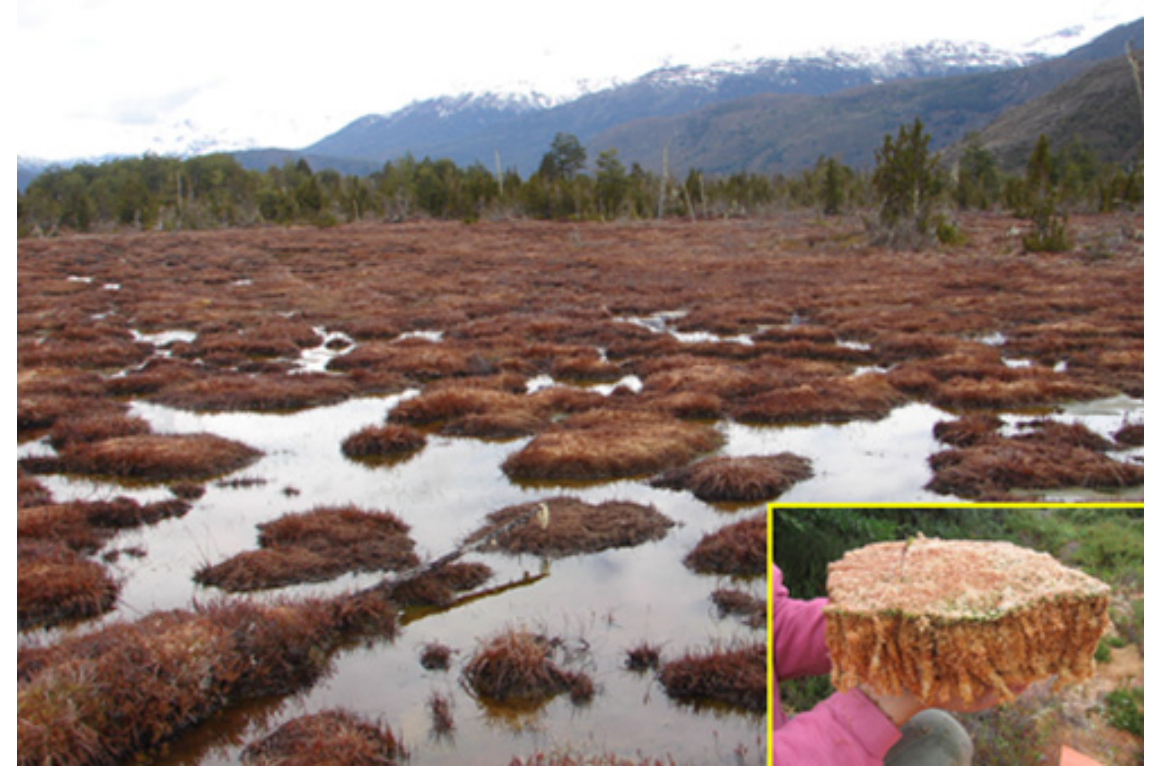

Figure 3. Sphagnum-bog with absolute dominion of Sphagnum magellanicum. The box shows the density with which their caulids grow. Near Cochrane (Aysén, Chile. $47^{\circ} \mathrm{S}$ ).

While we do not intend in this work to give a detaileddescription ofall thesyntaxaproposed for Sphagnum bogs (such as the alliances RostkovioSphagnion or Sphagnion magellanici, both invalid), we give a syntaxonomical checklist of the validly published association names, and as far as possible explain their characteristics.

\subsection{Gaultherio-Sphagnetum magellanici} Oberd. 1960

Lectotypus hoc loco Oberdorfer (1960), Tab. 43, rel. 246.
Although the relevés collected by the author are very species poor and the association is supported by only four relevés, it shows the floristic composition of Sphagnum bogs from NVald. Oberdorfer (1960) attempted to demonstrate that the northern areas also have Sphagnum bogs, forcing a merger with the associations sampled by Roivainen (1954) in Tierra del Fuego (2.2 and 2.3) in the alliance Gaultherio-Sphagnion. In addition to the dominance of Sphagnum magellanicum, which has very high cover values, other characteristic species are Gaultheria antarctica, G. caespitosa, Myrteola nummularia, Carex magellanica, $C$. 
camptoglochin and the occurrence of some cushion bog vascular species. The participation of some species that can be considered as members of the same community and a prelude to a progressive dynamic towards woody vegetation (Empetrum rubrum, Baccharis patagonica, Gaultheria mucronata, Austroblechnum penna-marina) can be deduced from more recent data (Díaz et al., 2008) taken on Chiloé Island. These communities are also colonised by bryophytes other than Sphagnum species (León, 2012), and this diversity is concealed in relevés focussing on vascular plants.

When proposing a name for this association, Oberdorfer (op. cit.) did not select a species from the genus Gaultheria. G. caespitosa is notable for its greater presence in its four inventories. Nevertheless, confusion with G. pumila may have caused its frequency to be overestimated, since both species have a similar habit, leaf size and marginal dentition, and both are easily mistaken unless the specimens have welldeveloped fruits (Teillier \& Escobar, 2013: 146). In recent studies on peatlands on Chiloé Island, several authors have identified the presence of $G$. antarctica in Sphagnum bogs (Díaz et al., 2008) and cushion bogs (Ruthsatz \& Villagrán, 1991), or G. pumila only in cushion bogs (Ramírez et al., 2014b), while none found G. caespitosa. In any case, due to the lack of certainty about the specimens collected by Oberdorfer, we propose to lectotypify the association in the only relevé that clearly identifies $G$. antarctica.

In this association and in the following associations with validly published names $(2.2,2.3$ and 2.4), there may be a presence of erect, herbaceous or woody species growing above the Sphagnum formations. However in none does the abundance of these reeds, sedges or shrubs attain the cover density that would require the association names to be modified in accordance with Article $29 \mathrm{~b}$ of the ICPN.

\subsection{Polytricho alpestris-Sphagnetum}

Oberd. 1960

Typus: does not exist.

Oberdorfer (1960, Table 44, column 'a') detailed the original diagnosis of this association as a column within a synoptical table, defined with 25 relevés provided by Roivainen (1954) in the eastern part of Tierra del Fuego, under a less rainy ombroclimate. This association is characterised by a high cover of bryophytes, low richness in vascular plant species and a significant participation of sedges. Characteristic bryophytes are Polytrichum alpestre, Sphagnum fimbriatum and Chorisodontium acyphyllum, in addition to the dominant Sphagnum magellanicum. Notable among the sedges/rushes are Rostkovia magellanica, Carex magellanica and Marsippospermum grandiflorum, although none occurs with the frequency or sufficient cover to invalidate the name "Sphagnetum". This vegetation is generally characterised by a thinner peat layer, which allows the establishment of some shrubs such as Empetrum rubrum, Nothofagus antarctica and Chiliotrichum diffusum.

The name proposed by Oberdorfer for this association did not specify the species of the Sphagnum genus used. Since there were two species, although the presence of S. magellanicum was much greater than $S$. fimbriatum (see our Table 1, rel. 13), the name of the association cannot specify more than "Sphagnetum".

\subsection{Caltho appendiculatae-Sphagnetum}

Oberd. 1960

Typus: does not exist.

As in the previous case, this community was described by Oberdorfer (1960, Table 44, column "b") with a synthesis of seven relevés from Roivainen (1954) from the rainier western Tierra del Fuego, corresponding to the Antiboreal Magellanian province. In contrast with 2.2 bryophytes are less frequent, although characterised by Dicranoloma hariotii, and there is a greater presence of vascular species such as Tetroncium magellanicum, Acaena pumila, Caltha appendiculata and Carpha schoenoides.

From a nomenclatural standpoint this association suffers the same problem as 2.2 , with the occurrence of two species of Sphagnum, although $S$. fimbriatum is less abundant. No authors have subsequently used this name to designate relevés, so it cannot be neotypified.

\subsection{Nanodeo muscosae-Sphagnetum magellanici ass. nova hoc loco}

Holotypus: Roig, Dollenz \& Méndez (1985), Tab. 48, gr. 75, rel. 63 [sub Carico-Sphagnetum nom. nud.]

This is a Sphagnum community forming typical hummocks; the highest part of these hummocks stands out above the ground water (and is thus known in German as "Bulte"), and they are maintained by abundant moisture from rainfall, though some aeration may occur 
inside Sphagnum magellanicum hummocks. According to Roig et al. (1985) and their observations at the latitude in which this community was described $\left(52^{\circ} \mathrm{S}\right)$, several species have an ecological affinity to those hummocks, such as Carex magellanica, C. camptoglochin and $C$. canescens, thus justifying their choice of the name Carico-Sphagnetum. There is also a presence of creeping or rhizomatous species such as Gaultheria pumila, Myrteola nummularia, Austroblechnum penna-marina and Nanodea muscosa. The last species was selected for inclusion in the association name due to its biogeographic relation to MAG, since this species is rare in NVald.

\subsection{Sphagnetum magellanici Pisano 1977 nom. illeg., nom. dub}

In an extensive study of MAG between $52^{\circ} \mathrm{S}$ and $56^{\circ} \mathrm{S}$, Pisano (1977) developed the concept of Magellanian tundra, considered as a complex of communities divided into three groups, 1) hummock bogs, 2) cushion bogs and 3) graminoid fens. The second corresponds to group 1 in this work, plus a model called "montane tundra", which is included in group 3. Graminoid fens are here included in group 4. The largest group in Pisano's work consisted of hummock communities, which were divided into 1) Sphagnum bogs in areas with less than $1500 \mathrm{~mm}$ of precipitation per year and characterised by $S$. magellanicum; and 2) bryophytic bogs dominated by mosses and liverworts with a lower participation of Sphagnum, more typical of areas with between 1500 and $2500 \mathrm{~mm}$ of precipitation per year or even higher. This author gave only one floristic composition for Sphagnum bogs, summarising them under the name Sphagnetum magellanici. This proposal was illegitimate as this name had been used previously to describe peatlands in the northern hemisphere (Kästner \& Flössner, 1933)

Pisano published his community "Sphagnetum magellanici" in a table with three columns: one for the typical association and the others for subassociations. Although this table gave a double quantitative index for each species, similar to a classical relevé under the Braun-Blanquet approach, it is not in fact a relevé but rather an integration of several floristic situations from different Sphagnum bogs where different species coexist. No locality is given for this single relevé, and the area relevéd is unspecified; however the main argument against it is that this is a floristic combination containing 46 species, $90 \%$ of which have cover higher than " 1 " in Braun-Blanquet scale, while all the other references show lists of eight to 15 species (see Table 1, where the associations have between 12 and 32 species). As shown in Table 1, "Sphagnetum magellanici" (column Sph) shares many species with 1.6, 1.7, 2.1 and 2.4, and also contains many species from group 3. Therefore, although "Sphagnetum magellanici Pisano 1977" were to receive a legitimate alternate name, it would continue to be a nomen dubium, requiring the application of Article 37 of the ICPN, since it is evidently a combination of different associations.

This is the main argument for rejecting the use of either the name or the concept expressed as "Sphagnetum magellanici Pisano 1977".

\subsection{Other proposals for Group 2}

In their explorations on Piazzi Island $\left(51^{\circ}\right.$ 40' S, MAG territory) Roig et al. (1985) described two more associations they related to the Sphagnum bog group and included in their alliance Sphagnion magellanici nomen nudum. In both cases the cover of Sphagnum magellanicum does not exceed 1\% (index "+"), and although these are two invalid names (Table $3)$, we show their floristic content in Table 1 . The first, Donatio-Sphagnetum magellanici nomen nudum, responds to a situation of a cushion/Sphagnum bog sensu Kleinebecker et al. (2007), or a transitional situation between the communities in group 1 and those in group 2. The second corresponds to a situation derived from the previous community in which there is an invasion of the rush Marsippospermum grandiflorum, with a dynamic situation towards the woody formation, as its authors recognise a stratum with Nothofagus betuloides and another with Chiliotrichum diffusum. We refrain from granting the new name to either of these two associations, as we interpret them as dynamic or contact situations that probably confuse rather than clarify the syntaxonomy of this vegetation type.

Information has recently been published on a Sphagnum bog present in the SVald territory in the region of Aysén (Teneb et al., 2008; Ramírez et al., in press). Although its authors do not assign a phytosociological name, its composition can be considered equivalent to 2.3 . 


\section{3. "Montane tundra" bogs}

Pisano (1977) used this name to refer to a type of cushion bog located in areas with rainfall of over $2000 \mathrm{~mm}$ and in "definitely mountain territories", specifying that they were located "on sloping rocky substrates or in areas with steep relief, often reaching the upper limit of the phanerogamic vegetation" (Pisano, op. cit.: 230). He gave an association name to represent this model: Bolax gummifera-Azorella selago, but did not provide any relevés and only cited certain species that he considered characteristic of this possible association.

Without referring to this proposal of Pisano (op. cit.), Roig et al. (1985) subsequently distinguished a type of communities in the Última Esperanza province (MAG territory, parallel $52^{\circ} \mathrm{S}$ ) that they estimated to be adifferent order within the class Myrteolo-Sphagnetea: the order Bolaco-Phyllachnetalia uliginosae. They defined them as "communities with a dominance of cushion plants with compact hard bodies, with low coverage on steeply sloping soils or on scree beds. These species are characteristic of the summits of slopes on ridges with extreme drainage and intensive erosive action of rain and wind" (Roig et al., op. cit.: 493). They also labelled them as "montane tundra" and provided a table to define them with five associations, all affected by the same problem of nomenclatural invalidity due to their lack of typification (see Table 3) and whose main content is shown in Table 2:

We venture no opinion on the first of the five associations they propose (sub Cryptochiletum grandiflorae) which describes a pioneering bryophytic community comprising only four bryophytic species and very few vascular plants.

We interpret the first two associations (rel. 1 and 2, Table 2) as clearly differentiable due to their floristic content. The typification is proposed as follows:

3.1. Senecio trifurcati-Bolacetum caespitosae, ass. nova hoc loco. Holotypus: Roig, Dollenz \& Méndez (1985), Table 52, group 78, rel. 66 (sub Bolaco-Phyllachnetum uliginosi nomen nudum).

3.2. Azorello selaginis-Bolacetum caespitosae, ass. nova hoc loco. Holotypus: Roig, Dollenz \& Méndez (1985), Table 52, group 79, rel. 83 (sub Azorello-Phyllachnetum uliginosi nomen nudum)

The third (col. 3, sub Astelio-Phyllachnetum uliginosi nomen nudum) could possibly be considered as a variant of the first, with greater soil moisture leading to dense carpets of Astelia pumila and the inclusion of Marsippospermum grandiflorum. However it can also be interpreted as a community similar to 1.6 in a situation of transition towards "Bolacetum caespitosae".

The fourth association (col. 4, sub LomatioDacrydietum foncki, nom. nud.) appears to be somewhat less clear due to the lack of characteristic species of the alliance and an abundant participation of shrubs and small trees that point to a dynamic process and the prelude to an evergreen forest in LomatioNothofagetum betuloidis, as recognised by Roig et al. (op. cit.: 498).

We therefore prefer to leave both the third and the fourth associations as nomina nuda while awaiting more data, as we have no personal experience of this type of vegetation in this territory.

An additional column ( $S p h)$ has been added to Table 2 with the floristic content of "Sphagnetum magellanici Pisano 1977", to show by comparison how the single relevé from this invalid association also covers a large part of the floristic content of this alliance.

\section{Sedge and grass bogs}

This category is intended to include a type of formation that is physiognomically differentiated due to an abundant density of "grass forms in which forbs have a coverage value of less than 50\%" (Pisano, 1977: 232). It should also be noted that the previous formations treated in groups 1-3, were described from the part of MAG territory with a humid or hyperhumid ombroclimate. In a subhumid and even dry ombroclimate, mainly in the territory of Tierra de Fuego and Patagonia in Argentina, a series of transitional wetlands have been cited between genuine bogs (Sphagnum or cushion) and hygrophilous pastures linked to favourable topographies, drains, etc. with little or no peat formation of the organic matter; these situations are included in what have been proposed as the classes Calthetea, Hordeetea pubiflori, and even Rostkovietea (Roig et al., 1985), which all bear a relation to the seasonal nature of the water flooding them, as the ombroclimate is less humid. 
Table 2. Abrotanello-Bolacion.

Floristic composition of the four main associations published by Roig et al. (1985) as representatives of peatland communities of 'Montane tundra bogs'. Associations represented in columns 1 and 2 were accepted and typified in this paper; associations represented in columns 3 and 4 still remain as nomen nudum (see the text). As it was shown in Table 1, the coincident flora integrating the Sphagnetum magellanici Pisano 1977 is exposed in column Sph (rel. 5) to underline the mixture character of that association.

\begin{tabular}{|c|c|c|c|c|c|}
\hline $\begin{array}{l}\text { Assoc Code } \\
\text { Nr. of relevés } \\
\text { Relevé N. }\end{array}$ & $\begin{array}{c}3.1 \\
9 \\
1\end{array}$ & $\begin{array}{c}3.2 \\
8 \\
2\end{array}$ & $\begin{array}{l}3 \\
5 \\
3\end{array}$ & $\begin{array}{l}4 \\
6 \\
4\end{array}$ & $\begin{array}{c}\text { Sph } \\
1 \\
5\end{array}$ \\
\hline \multicolumn{6}{|l|}{\begin{tabular}{|l|} 
Differentials of associations \\
\end{tabular}} \\
\hline Cryptochila grandiflora & IV & . & . & . & \\
\hline Senecio trifurcatus & $\mathrm{V}$ & & . & . & 1 \\
\hline Azorella selago & . & IV & . & . & 3 \\
\hline Austrolycopodium alboffii & . & III & . & . & . \\
\hline Abrotanella trichoachaenia & . & I & . & . & . \\
\hline Carex kingii & . & I & . & . & . \\
\hline Conostomum pentastichum & . & . & . & II & \\
\hline Lepidothamnus fonkii & . & . & 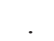 & $\mathrm{V}$ & 1 \\
\hline \multicolumn{6}{|l|}{ Abrotanello-Bolacion caespitosae } \\
\hline Perezia magellanica & V & II & IV & $\mathrm{V}$ & + \\
\hline Austrolycopodium confertum & II & II & II & $\mathrm{V}$ & . \\
\hline Drapetes muscosus & I & IV & I & I & \\
\hline Bolax caespitosa & IV & $\mathrm{V}$ & $\mathrm{V}$ & . & 2 \\
\hline Phyllacne uliginosa & $\mathrm{V}$ & II & $\mathrm{V}$ & . & 1 \\
\hline Orthachne rariflora & II & IV & . & . & . \\
\hline Azorella lycopodioides & II & I & . & . & 2 \\
\hline Viola tridentata & I & I & & . & . \\
\hline Andreaea sp. & . & IV & I & . & . \\
\hline Austrolycopodium magellanicum & . & I & . & I & . \\
\hline \multicolumn{6}{|l|}{ Myrteolo-Sphagnetea species } \\
\hline Oreobolus obtusangulus & $\mathrm{V}$ & II & III & IV & 1 \\
\hline Gaultheria pumila & $\mathrm{V}$ & IV & IV & III & 3 \\
\hline Gaimardia australis & $\mathrm{V}$ & I & IV & IV & 1 \\
\hline Donatia fascicularis & II & I & III & III & 2 \\
\hline Tapeinia pumila & IV & I & III & II & 2 \\
\hline Caltha dioneifolia & IV & $\mathrm{V}$ & IV & III & 1 \\
\hline Thamnolia vermicularis & IV & I & II & III & . \\
\hline Carpha schoenoides & I & I & II & . & 1 \\
\hline Schoenus antarcticus & III & . & I & IV & 1 \\
\hline Pinguicula antarctica & I & . & I & I & . \\
\hline Abrotanella linearifolia & III & II & & . & \\
\hline Nanodea muscosa & I & . & II & & 2 \\
\hline Drosera uniflora & II & & & III & 2 \\
\hline Rostkovia magellanica & . & II & I & & 1 \\
\hline Caltha appendiculata & . & II & & III & 2 \\
\hline Astelia pumila & . & & $\mathrm{V}$ & II & 2 \\
\hline Tribeles australis & . & II & & . & \\
\hline Marsippospermum grandiflorum & . & . & III & ${ }^{\circ}$ & 2 \\
\hline Myrteola nummularia & . & . & . & $\mathrm{V}$ & 2 \\
\hline Acaena pumila & . & . & . & $\mathrm{V}$ & 1 \\
\hline \multirow{2}{*}{\multicolumn{6}{|c|}{ Wintero-Nothofagetea species }} \\
\hline & & & & & \\
\hline Nothofagus antarctica & IV & I & & I & 2 \\
\hline Embothrium coccineum & . & II & I & I & \\
\hline Nothofagus betuloides & . & I & I & $\mathrm{V}$ & 2 \\
\hline Philesia magellanica & . & I & 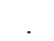 & III & 1 \\
\hline Lomatia ferruginea & . & . & : & V & \\
\hline Pilgerodendron uviferum & 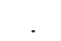 & . & . & III & 2 \\
\hline Berberis ilicifolia & . & . & 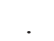 & I & . \\
\hline Escallonia serrata & . & . & . & I & . \\
\hline Drimys winteri & . & . & . & I & + \\
\hline Lebetanthus myrsinites & . & . & . & IV & \\
\hline Empetrum rubrum & . & . & . & I & 3 \\
\hline Berberis microphylla & & & & I & 2 \\
\hline
\end{tabular}




\begin{tabular}{|c|c|c|c|c|c|}
\hline \\
\hline \multicolumn{6}{|l|}{ Cortaderia pilosa } \\
\hline Gaultheria mucronata & I & . & . & I & 1 \\
\hline Gunnera magellanica & . & . & . & II & 2 \\
\hline Racomitrium lanuginosum & . & 1 & & . & . \\
\hline Baccharis patagonica & . & - & II & . & . \\
\hline Juncus balticus & & & & $\mathrm{I}$ & \\
\hline $\begin{array}{l}\text { Relevé source: 1: Senecio } \\
\text { Bolaco-Phyllacnetum ulig } \\
\text { Bolacetum caespitosae. R } \\
\text { Dollenz \& Méndez } 1985 \\
1985 \text { nom. nud. Roig \& a } \\
\text { Méndez } 1985 \text { nom nud. Ro } \\
\text { Tb. XXI. [Including anoth }\end{array}$ & $\begin{array}{l}\text {, gr } \\
\text {; } P h \\
\text { gr. }\end{array}$ & & $\begin{array}{l}\text { nud } \\
\text { Phyl } \\
\text { osi } \mathrm{R} \\
\text { etun } \\
\text { m mo }\end{array}$ & $\mathrm{R}$ & $\begin{array}{l}8 \text { sub } \\
\text { aginis- } \\
i \text { Roig, } \\
\text { léndez } \\
\text { lenz \& } \\
1977,\end{array}$ \\
\hline
\end{tabular}

Roig (1998) recognised six types of peatlands for the whole of the Argentinian part of Patagonia, two of which he called "Marsippospermum grandiflorum" peatlands and "waterlogged peatlands with Schoenus andinus and Carpha schoenoides". Although he did not describe any floristic composition or relevés, his intention was to express certain repeated physiognomic models. In the collection by Martínez-Carretero (2004), gradual floristic changes can be observed in Tierra de Fuego from carpets of Astelia pumila and Sphagnum bogs of Sphagnum magellanicum through to various moist peat meadows with the participation of different sedges depending on the case: Carex gayana, C. magellanica, $C$. banksii, C. canescens, C. camptoglochin, and others. However this author omitted to give names to any of their communities.

There was at least one proposal for a phytosociological association in Chilean territory to describe a type of sedge-grass peatland. Pisano himself (op . cit.) proposed Schoenetum antarctici, and gave a description accompanied by one relevé. However, his single published relevé suffered from the same problem as his "Sphagnetum magellanici", as explained above: one relevé with 47 species of which over two thirds have an abundance index of " 2 " or higher. We are therefore of the opinion that it should also be taken as a nomen dubium, and is not suitable to serve as the nomenclatural type for any association.

Very recently we have highlighted the existence of sedge-grass bogs in the SVald territory with the collection of 40 relevés from the region of Aysén, which we have named "community of Cortaderia pilosa and Schoenus andinus" with mean species richness of 14 species per relevé (Ramírez et al., in press).
The detailed study of these peaty grass formations throughout the SVald and particularly MAG may allow us in future to arrive at a phytosociological definition of this type of vegetation, whose species are often imbricated with communities from Groups 1-3.

\section{Rejected names of the syntaxa}

Table 3 shows a list of names of associations or higher rank syntaxa that have been discarded for reasons of invalidity. Although their concept of community may be acceptable (1, 4, 11 and 12 have been recovered to typify new names), their name is not, and must therefore be rejected.

One of the works with the largest contribution of nomenclatural proposals describing associations that ecologically differentiate the various peatlands in MAG, Roig et al. (1985), fails to comply in all its proposals with the requirement of choosing a nomenclatural type (article 5 of the ICPN), so the name of associations proposed (1 to 4 and 9 to 14 in Table 3 ) are invalid.

The name of association 5 is a clear case of nomen superfluum: Schwaar (1976) studied a community in Tierra de Fuego which he called Pernettyo-Sphagnetum magellanici, supported by 14 relevés whose floristic content in its typical subassociation barely exceeded six species; however, this composition is identical to the one previously studied by Roivainen (1954) and which Oberdorfer (1960) proposed to call Polytricho alpestris-Sphagnetum.

The problems with the names of associations 7 and 8 have already been explained as nomen dubium: their names should not be used, and nor should Pisano's relevés (1977), to typify new names. 
The case of association 15 represents a flawed attempt to use data from a classic work. San Martín et al. (1999) proposed the name Astelio-Oreoboletum obtusangulae to designate a type of cushion bog recognized in the NVald territory. However they typified it by choosing a relevé from an association published by Oberdorfer (1960) under a different name: Schoeno-Oreoboletum. Given that this is a validly published name (see association 1.1), "Astelio-Oreoboletum" is a nomen superfluum which must be rejected by application of article 29 c of the ICPN.

A particular case is the work of Roivainen (1954), who left an extensive sample of floristic combinations found throughout numerous peatlands releved on 73 different sites in Tierra de Fuego in Chile and Argentina; he also supplied an even greater number of names for the different combinations he found on each site. There are examples of species combinations with no community name, while others in contrast are designated with binomials, trinomials or tetranomials ("species A + species $\mathrm{B}+$ species $\mathrm{C}+$ species D Soziationen"). We understand all these denominations, abbreviated as "-Soz.", to be invalid, by the application of article $3 d$ (which refers to Principle II) of the ICPN.

Some proposed alliance names for groups of peatland associations must also be considered as nomina nuda and rejected according to ICPN specifications:

- Rostkovio-Sphagnion magellanici, proposed by Knapp (1966) and defended in some more recent works (San Martín et al., 1999), has never had a validly published association that could be used as a type to support it.

- Donation fascicularis has been proposed as an alliance name on two occasions. However the first proposal by Roig et al. (1985) combining associations in MAG had no type association; and the second, by San Martín et al. (1999), is obviously invalid as it uses an identical name to a previous published name.

- The name Astelion pumilae, proposed by San Martín et al. (1999), was typified on the association Astelio-Oreoboletum obtusangulae which is invalid, as explained above. As a result the typification of this alliance is illegitimate.

- The proposal of Sphagnion magellanici by Roig et al. (1985) is a case of the application of Article 31 of the ICPN, as this name was used much earlier (Kästner \&
Flössner, 1933) for peatland in the Northern Hemisphere. Other syntaxa as the alliance Bolaco-Phyllachnion and its order BolacoPhyllachnetalia suffers the same problem as all names published by Roig et al. (op. cit.): the absence of typification.

\section{Conclusions}

Regardless of the possible existence of peatland vegetation units described based on some of their attributes, but which have not received an orthodox name according to the rules of the ICPN, by combining all the phytosociological communities that have indeed been validly named (Groups 1-3), we can arrive at a consistent taxonomical ordination to further the interpretation of this type of vegetation in the Valdivian-Magellanian region:

There are communities in the so-called Magellanian tundra from parallel $40^{\circ}$ to $56^{\circ}$ south that are identifiable for maintaining a reasonably constant floristic composition in spite of covering such a broad distribution area. Although there is a much greater extension and abundance of these peatlands in MAG, there is no floristic contingent present in MAG that does not extend as far as NVald territory, with the exception of some characteristic species from the associations in Group 3 (the "montane tundra"), a group that we interpret as genuinely and exclusively belonging to MAG.

Analyzing Groups 1 and 2 in combination (which will subsequently be included as phytosociological alliances), the floristic variations that can be detected among associations in the same group are not due to biogeographical but to climatic, topographic and dynamic factors, to factors relating to the water table, or because the relevés have been taken in points of contact between communities. Very few species can be used for a biogeographical discrimination (Chusquea montana exclusive to NVald, and reciprocally Drapetes muscosus exclusive to MAG, see Zuloaga et al., 2009). We therefore do not consider it justifiable to establish more alliances within these groups; proposals such as "Donation fascicularis" or "Astelion pumilae" have been put forward more for reasons of circumstantial abundance of some of the dense carpet-forming species than for the discrimination of species of flora. 
Table 3. Names of associations, alliances or order rejected following ICPN. The right column specifies the ICPN articles involved.

\begin{tabular}{|c|c|c|c|}
\hline N. & Syntaxon & Authors \& publication date & ICPN \\
\hline 1 & Donatietum fascicularis & Roig et al. 1985 & Art. 5 \\
\hline 2 & Schoeno-Nothofagetum antarcticae & Roig et al. 1985 & Art. 5 \\
\hline 3 & Donatio-Sphagnetum magellanici & Roig et al. 1985 & Art. 5 \\
\hline 4 & Carico-Sphagnetum magellanici & Roig et al. 1985 & Art. 5 \\
\hline 5 & Pernettyo-Sphagnetum magellanici & Schwaar 1976 & Art. 29c \\
\hline 6 & Marsippospermetum grandiflorae & Pisano 1977 & Art. 2b, Art. 7 \\
\hline 7 & Sphagnetum magellanici & Pisano 1977 & Art. 31, Art. 37 \\
\hline 8 & Schoenetum antarcticae & Pisano 1977 & Art. 37 \\
\hline 9 & Marsippospermetum grandiflorae & Roig et al. 1985 & Art. 5, Art. 22 \\
\hline 10 & Cryptochiletum grandiflori & Roig et al. 1985 & Art. 5 \\
\hline 11 & Bolaco-Phyllachnetum uliginosi & Roig et al. 1985 & Art. 5 \\
\hline 12 & Azorello-Phyllachnetum uliginosi & Roig et al. 1985 & Art. 3g, Art. 5 \\
\hline 13 & Astelio-Phyllachnetum uliginosi & Roig et al. 1985 & Art. 5 \\
\hline 14 & Lomatio-Dacrydietum fonckii & Roig et al. 1985 & Art. 5 \\
\hline 15 & Astelio-Oreoboletum obtusangulae & San Martín \& al. 1999 & Art. 22, Art. 29 \\
\hline 16 & Rostkovio-Sphagnion magellanici & Knapp 1966 & Art. 2b, Art. 8 \\
\hline 17 & Donation fascicularis & Roig et al. 1985 & Art. 5 \\
\hline 18 & Bolaco-Phyllachnion & Roig et al. 1985 & Art. 5 \\
\hline 19 & Donation fascicularis & San Martín et al. 1999 & Art. 31 \\
\hline 20 & Astelion pumilae & San Martín et al. 1999 & Art. 17 \\
\hline 21 & Sphagnion magellanici & Roig et al. 1985 & Art. 31 \\
\hline 22 & Bolaco-Phyllachnetalia & Roig et al. 1985 & Art. 5 \\
\hline
\end{tabular}

The variety of ecological processes that converge in the formation and evolution of peatlands frequently produces different morphological types deriving largely from the abundance or dominance of a particular species; this has caused some botanists to promote association names based on the prominence of this circumstantially dominant species. This is particularly true in the case of cushion bogs, where associations have been identified such as Oreoboletum, Donatietum or Astelietum, depending on the abundance of any of these three species (the three genera Oreobolus, Donatia and Astelia are monospecific in this territory); however, Marsippospermetum grandiflori or Lepidothamnetum fonkii have also been proposed due to the abundance of these two species in various circumstances. The dominance of certain species is often simply a question of changes in the depth of the water table, the thickness of the peat layer, the dynamic phase of evolution towards woody communities, and so on. In these cases it is advisable to make a closer study of the water and nutritional dynamic of these peatlands and interpret any notable proliferation of certain species as simple variants or facies of some already known association.

\section{Syntaxonomical checklist}

We summarize the set of communities that we have so far confirmed as validly published in a syntaxonomical ordination (Appendix 1). Based on the floristic contents of the associations shown in Tables 1 and 2, it can be concluded that:

It is reasonable to establish three phytosociological alliances with each one of the three groups of the previously explained associations. We exclude recognition of any community in Group 4 while awaiting more data from the whole of the VP territory.

In group 3 we recognize two clearly differentiated associations, although we include another two in Table 2, as nomina nuda, whose identity requires careful study. We consider their differentiating flora appear to be sufficient for this group, and therefore propose the alliance Abrotanello 
linearifoliae-Bolacion caespitosae all. nova hoc loco [Syn. Bolaco-Phyllachnion Roig et al. 1985 nom. nud. p.p.]. Typus nominis: Azorello selaginis-Bolacetum caespitosaeAmigo et al. ass. nova. Characteristics of the alliance: Perezia magellanica,Drapetes muscosus, Austrolycopodium confertum, Bolax caespitosa, Phyllachne uliginosa, Azorella lycopodioides and Orthachne rariflora.

Group 2 contains the Sphagnum associations in which a massive coverage of Sphagnum tends to serve as the primary selective criterion; this has sometimes led to the interpretation of "Sphagnetum" for peat formations in very different dynamic stages, or imbricated with cushion bogs. Table 1 contains a pair of communities published as nomina nuda, which have a floristically dissonant composition. For the four associations recognised we maintain the oldest validly published alliance name Gaultherio-Sphagnion magellanici Oberd. 1960. Typus nominis: GaultherioSphagnetum magellanici. Characteristic species: Sphagnum magellanicum, Carex magellanica, Nanodea muscosa, Sphagnum fimbriatum, Rostkovia magellanica, Chorisodontium aciphyllum, Polytrichum alpestre, Carex canescens, Gaultheria antarctica.

The association that serves as the type for this alliance, an obligatory selection under the terms of the ICPN (Art. 20), is floristically very poor; this should not be interpreted as a pretext for proposing as many new associations as there may be cases of Sphagnum bogs with the simple participation of a species that is not present in this association. The goal of a rational syntaxonomy is to address all the floristic variations that can contribute some biogeographical significance, and the participating vascular flora does not offer many possibilities. A greater knowledge on species composition of the moss layer (bryophytes and lichens) of these peatlands would potentially make a more valuable contribution in this regard as indicated by the results of Villagra et al. (2009), and particularly by the recent contribution of Quilhot et al. (2012).
Group 1, in which most associations have been recognised, also has the clearest floristic contingent, and is also the group for which most alliance names have been proposed, with the lack of validity explained above. It must have the oldest validly published name, namely Astelio pumilae-Oreobolion obtusanguli Oberd. 1960. Lectotypus nominis in hoc loco: Caltho-Oreoboletum obtusanguli Oberd. 1960. Characteristic species: Oreobolus obtusangulus, Astelia pumila, Donatia fascicularis, Tapeinia pumila, Gaimardia australis, Tribeles australis, Caltha dioneifolia.

The set of three alliances, given the level of imbrication of the shared flora in all their associations, may be integrated in the single order Myrteolo-Sphagnetalia magellanici. Lectotypus nominis in hoc loco: Astelio pumilae-Oreobolion obtusanguli Oberd. 1960. Characteristic species: Acaena pumila, Caltha appendiculata, Carpha schoenoides, Droserauniflora, Gaultheriapumila, Marsippospermum grandiflorum, Myrteola nummularia, Perezia lactucoides, Pinguicula antarctica, Tetroncium magellanicum.

We consider there still to be insufficient information to accept the proposal of a second order such as "Bolaco-Phyllachnetalia nomen nudum" for the formations we include in Group 3. Among other reasons, a clear distinction must be made between these moderately peat-forming associations of Abrotanello-Bolacion caespitosae and the nearby associations in clearly cryorophilous communities in the class Empetro-Bolacetea (Roig et al., 1985).

\section{Acknowledgments}

We would like to thank Prof. Jesús Izco (Santiago de Compostela) for his help with some nomenclatural aspects and with the proper implementation of the ICPN; L.G. Orellana for the preparation of maps, and P. Brooke-Turner for the linguistic revision of the manuscript.

\section{References}

Álvarez, M., San Martín, C., Novoa, C., Toledo, G. \& Ramírez, C. 2010. Diversidad florística, vegetacional y de hábitats en el archipiélago de Los Chonos (Región de Aisén, Chile). An. Inst. Patagonia 38: 34-55.

Amigo, J. \& Ramírez, C. 1998. A bioclimatic classification of Chile: woodland communities in the temperate zone. Plant Ecol. 136: 9-26. 
Anonymous. 2013. The Plant List. Database, ver. 1.1. R. Bot. Gard., Kew and Missouri Bot. Gard. http:// www.theplantlist.org/ (accessed 2017 April 20)

Auer, V. 1965. The Pleistocene of Fuego-Patagonia. Part IV: Bog Profiles. Ann. Acad. Sci. Fenn., Ser. AII, 80: 1-160.

Barkman, J., Moravec, J. \& Rauschert, S. 1976. Code of Phytosociological Nomenclature. Vegetatio 32(3): 131-185.

Blanco, D.E. \& de la Balze, V.M. (Eds.). 2004. Los turbales de la Patagonia: Bases para su inventario y la conservación de su biodiversidad. Publ. 19. Wetlands Int., Buenos Aires. 150 pp.

Bonarelli, G. 1917. Tierra del Fuego y sus turberas. An. Min. Agric. Nac. Secc. Geol., Min. Min. Tomo XII (3), Buenos Aires. 119 pp.

Cabrera, A.L. \& Willink, A. 1973. Biogeografía de América Latina. Secretaría General de la Organización de los Estados Americanos, Washington. 117 pp.

Deil, U., Alvarez, M., Bauer, E.M. \& Ramírez, C. 2011. The vegetation of seasonal wetlands in extratropical and orotropical South America. Phytocoenologia 41(1): 1-34.

Díaz, M.F., Larraín, J., Zegers, G. \& Tapia, C. 2008. Caracterización florística e hidrológica de turberas de la Isla Grande de Chiloé, Chile. Rev. Chil. Hist. Nat. 81: 455-468.

Dollenz, O. 1980. Estudios fitosociológicos en el Archipiélago Cabo de Hornos. An. Inst. Patagonia 11: 223-238.

Dollenz, O. 1982. Estudios fitosociológicos en las Reservas Forestales Alacalufes e Isla Riesco. An. Inst. Patagonia 13: 161-169.

Dollenz, O. 1986. Relevamientos fitosociológicos en la Península Muñoz Gamero, Magallanes. An. Inst. Patagonia 16: 55-62.

Gasper, A.L., Dittrich, V.A.O., Smith, A.R. \& Salino, A. 2016. A classification for Blechnaceae (Polypodiales: Polypodiopsida): New genera, resurrected names, and combinations. Phytotaxa 275(3): 191-227.

Godley, E. 1960. The botany of Southern Chile in relation to New Zealand and the subantartic. Proc. Roy. Soc. London B 152: 457-475.

Izco, J. \& Del Arco, M. 2003. Código Internacional de Nomenclatura Fitosociológica. Traducción de la $3^{\mathrm{a}}$ edición oficial. Mat. Did. Univ. Ser. Bot., 2. Serv. Publ. Univ. La Laguna. 160 pp.

Joosten, H. \& Clarke, D. 2002. Wise use of mires and peatlands. Background and principles including a framework for decision-making. Int. Mire Conserv. Gr. \& Int. Peat Soc. Saarijarvi, Finland. $304 \mathrm{p}$.

Josse, C., Navarro, G., Comer, P., Evans, R., Faber-Langendoen, D., Fellows, M., Kitte, G., Menard, S., Pyne, M., Reid, M., Schulz, K., Snow, K. \& Teague, J. 2003. Ecological Systems of Latin America and the Caribbean: A Working Classification of Terrestrial Systems. Nature-Serve, Arlington.

Kästner, M. \& Flössner, W. 1933. Die Pflanzengesellschaften der erzgebirgischen Moore. In: Kästner, M., Flössner, W. \& Uhlig, J. (Eds.). Die Pflanzengesellschaften des westsächsischen Berg-und Hügellandes. II. Veröff. Landesver. Sächs. Heimatschutz z. Erforsch., Pflanzenges. d. Freistaats Sachsen u. d. Angrenz. Naturgeb., Dresden.

Kleinebecker, T., Hölzel, N. \& Vogel, A. 2007. Gradients of continentality and moisture in South Patagonian ombrotrophic peatland vegetation. Folia Geobot. 42: 363-382.

Kleinebecker, T., Hölzel, N. \& Vogel, A. 2008. South Patagonian ombrotrophic bog vegetation reflects biogeochemical gradients at the landscape level. J. Veg. Sci. 19: 151-160.

Kleinebecker, T., Hölzel, N. \& Vogel, A. 2010. Patterns gradients of diversity in South Patagonian ombrotrophic peat bogs. Austral Ecol. 35: 1-12.

Knapp, R. 1966. Höhere Vegetations-Einheiten von Süd-Patagonien und Feuerland. Geobotanische Mitteilungen 35: 1-4.

Landrum, L. 1988. The myrtle family (Myrtaceae) in Chile. Proc. Calif. Acad. Sci. 45 (12): 277-317

León, C.A. 2012. Caracterizacion florística y ecológica de turberas esfagnosas de la isla grande de Chiloé, Chile: una herramienta para la conservación y el desarrollo sostenible. Mem. Doc. (inéd). Dep. Biol. Veg. I. Univ. Compl., Madrid.

Luebert, F. \& Pliscoff, P. 2006. Sinopsis bioclimática y vegetacional de Chile. Ed. Universitaria, Santiago de Chile. 316 pp.

Malvárez, A.I., Kandus P. \& Carbajo, A. 2004. Distribución regional de los turbales en Patagonia (Argentina y Chile). In: Blanco, D.E. \& Balze, V.M. (Eds.). Los turbales de la Patagonia: Bases para su inventario y la conservación de su biodiversidad. Pp. 23-29. Publ. 19. Wetlands Int., Buenos Aires. 
Martínez-Carretero, E. 2004. Los turbales patagónicos. In: Blanco D. E. \& V.M. de la Balze (Eds.). Los turbales de la Patagonia: Bases para su inventario y la conservación de su biodiversidad. Pp. 45-49. Publ. 19. Wetlands Int., Buenos Aires.

Moore, D.M. 1983. Flora of Tierra del Fuego. Nelson \& Missouri Bot. Gard.

Morrone, J.J. 2001. Biogeografía de América Latina y el Caribe. M\&T, Manuales y Tesis SEA, Zaragoza.

Oberdorfer, E. 1960. Pflanzensoziologische studien in Chile. Flor. Veg. Mundi 2: 1-208. J. Cramer, Weinheim.

Pisano, E. 1971. Comunidades vegetales del área del Fiordo Parry, Tierra del Fuego. An. Inst. Patagonia 2: 93-133.

Pisano, E. 1972. Comunidades vegetales del área de Bahía Morris, Isla Capitán Aracena, Tierra del Fuego (Parque Nacional Hernando de Magallanes). An. Inst. Patagonia 3:103-130.

Pisano, E. 1973. Fitogeografia de la Península Brunswick, Magallanes. An. Inst. Patagonia 4: 141-205.

Pisano, E. 1977. Fitogeografía de Fuego-Patagonia Chilena. I. Comunidades vegetales entre los $52^{\circ}$ y $56^{\circ}$ S. An. Inst. Patagonia 8: 121-250.

Pisano, E. 1983. The Magellanic tundra complex. In: Gore, A.J.P. (Ed.). Mires: swamp, bog, fen and moor. Pp. 295-329. Ecosystems of the world 4. Elsevier, Amsterdam.

Quilhot, W., Cuellar, M., Díaz, R., Riquelme, F. \& Rubio, C. 2012. Lichens of Aisén, Southern Chile. Gayana Bot. 69(1): 57-87.

Ramírez, C. 1968. Die Vegetation der Moore der Cordillera Pelada, Chile. Ber. Oberhess. Ges. Natur-Heilk. Giessen Naturwiss. Abt. 36: 95-101

Ramírez, C., San Martín, C., Sandoval, V., Amigo, J., Álvarez, M., Vidal, O., Toledo G. \& Pérez Y. Turbales de la Región de Aysén (Patagonia Chilena): Clasificación y ordenación de la flora y la vegetación. Gayana Bot. (In press).

Ramírez, C., Ortiz, I., San Martín, C., Vidal, O., Álvarez, M., Pérez, Y., Solís, J.L., Álvarez, I. 2014a. Estudio preliminar de la biodiversidad vegetal terrestre en el estero Walker (Región de Aysén, Chile): utilizando líneas base de proyectos de inversión. Gayana Bot. 71(2): 237-256.

Ramírez, C., San Martín, C., Vidal, O., Pérez, Y., Valenzuela, J., Solís, J.L. \& Toledo, G. 2014b. Tundra subantártica en la Isla Grande de Chiloé, Chile: Flora y Vegetación Turbosa de Campañas. An. Inst. Patagonia 42(2): 17-37.

Reiche, C. 1907. Grundzüge der Pflanzenverbreitung in Chile. Die Vegetation der Erde, VIII. Leipzig

Rivas-Martínez, S. 1993. Bases para una nueva clasificación bioclimática de la Tierra. Folia Bot. Matritensis 10: $1-23$.

Rivas-Martínez, S. 2016. Global Bioclimatics (Clasificación Bioclimática de la Tierra). www. globalbioclimatics.org/book/publications.htm [accessed 2017 March 25].

Rivas-Martínez, S., Navarro, G., Penas, A. \& Costa, M. 2011a. Biogeographic Map of South America. A preliminary survey. International Journal of Geobotanical Research 1: 21-40+Map

Rivas-Martínez, S., Rivas-Saenz, S. \& Penas, A. 2011b. Worldwide bioclimatic classification system. Global Geobotany 1: 1-634 + 4 Maps

Rodríguez-Martínez, A.C. 2015. Hydrogeomorphic classification of mire ecosystems within the Baker and Pascua Basins in the Region Aysén, Chilean Patagonia: a tool for their assessment and monitoring. Dissert. Dr. Rer. Agr., Humboldt-Universität Berlin. 272 p.

Roig, C. 2004. Antecedentes sobre turberas en Tierra del Fuego. In: Blanco D. E. \& V.M. de la Balze (Eds.). Los turbales de la Patagonia: Bases para su inventario y la conservación de su biodiversidad. Pp. 33-44. Publ. 19. Wetlands Int., Buenos Aires.

Roig, F.A. 1998. La vegetación de la Patagonia. In: Correa, M.N. (Ed.). Flora Patagonica, Parte I. Pp. 48166. Col. Ci. INTA, Buenos Aires.

Roig, F.A., Dollenz, O. \& Méndez, E. 1985. La vegetación de los canales. Segunda parte. In: Boelcke, O., Moore, D.M. \& Roig, F.A. (Eds.). Transecta Botánica de la Patagonia Austral. Pp. 457-519, Buenos Aires.

Roig, C. \& Roig, F.A. 2004. Consideraciones generales. In: Blanco D. E. \& V.M. de la Balze (Eds.). Los turbales de la Patagonia: Bases para su inventario y la conservación de su biodiversidad. Pp. 5-21. Publ. 19. Wetlands Int., Buenos Aires.

Roivainen, H. 1954. Studien über die Moore Feurlands. An. Bot. Soc. Zool. Bot. Fenn. Vanamo 28(2): 1-205.

Ruiz, E. 2001. Ranunculaceae Juss. In: Marticorena, C. \& Rodríguez, R. (Eds.). Flora de Chile, vol. 2. Winteraceae-Ranunculaceae. Pp. 40-94. Univ. Concepción, Concepción. 
Ruthsatz, B. \& Villagrán, C. 1991. Vegetation pattern and soil nutrients of a Magellanic moorland on the Cordillera de Piuché, Chiloé Island, Chile. Rev. Chil. Hist. Nat. 64: 461-478.

San Martín, C., Ramírez, C. \& Álvarez, M. 2004. Estudio de la vegetación de Mallines y Campañas en la Cordillera Pelada (Valdivia, Chile). Rev. Geogr. Valparaíso 35: 261-273.

San Martín, C., Ramírez, C. \& Figueroa, H. 1999. Análisis multivariable de la vegetación de un complejo de turberas en Cordillera Pelada (Valdivia, Chile). Lazaroa 20: 95-106.

Schlatter, R.P. \& Schlatter, J.E. 2004. Los turbales de Chile. In: Blanco, D.E. \& de la Balze, V.M. (Eds.). Los turbales de la Patagonia: Bases para su inventario y la conservación de su biodiversidad. Pp. 75-80. Publ. 19. Wetlands Int., Buenos Aires.

Schmithüsen, J. 1953. Die Grenzen der chilenischen Vegetationsgebiete. Deutscher Geographentag Essen, Tag. Wiss. Abhand. 1: 101-108.

Schwaar, J. 1976. Die Hochmoore Feuerlands und ihre Pflanzengesellschaften. Telma 6: 51-59.

Schwaar, J. 1981. Amphi-arktische Pflanzengesellschaften in Feuerland. Phytocoenologia 9(4): 547-572.

Teillier, S. \& Escobar, F. 2013. Revisión del género Gaultheria L. (Ericaceae) en Chile. Gayana Bot. 70(1): 136-153.

Teneb, E., Gómez, P. \& González, M. 2008. Observaciones sobre la flora y vegetación de dos turberas en la región de Aisén, Patagonia chilena. Gayana Bot. 65(2): 229-232.

Valenzuela, J. \& Schlatter, R. 2004. Las turberas de Cordillera Pelada, provincia de Valdivia (X Región, Chile). In: Blanco D. E. \& V.M. de la Balze (Eds.). Los turbales de la Patagonia: Bases para su inventario y la conservación de su biodiversidad. Pp. 81-85. Publ. 19. Wetlands Int., Buenos Aires.

Villagra, J., Montenegro, D., San Martín, C., Ramírez, C. \& Álvarez, I. 2009. Estudio de la flora liquénica de las turberas de la comuna de Tortel (Región de Aisén) Patagonia chilena. An. Inst. Patagonia (Chile) 37(1): 53-62.

Wardle, P. 1991. Vegetation of New Zealand. Cambridge University Press.

Wardle, P., Ezcurra, C., Ramírez, C. \& Wagstaff, S. 2001. Comparison of the flora and vegetation of the southern Andes and New Zealand. New Zealand J. Bot. 39: 69-108.

Weber, H.E., Moravec, J. \& Theurillat, J.P. 2000. International code of phytosociological nomenclature, 3rd edition. J. Veg. Sci. 11: 739-768.

Zuloaga, F., Morrone, O. \& Belgrano, M. 2009. Catálogo de Las Plantas Vasculares del Cono Sur: (Argentina, Sur de Brasil, Chile, Paraguay y Uruguay). Mon. Syst. Bot. Missouri Bot. Gard., Vol. 107. Missouri Bot. Gard. Press.http://www2.darwin.edu.ar/proyectos/FloraArgentina/FA.asp (accessed 2017 April)

Appendix 1. Phytosociological typology of the recognized syntax (valid names). In brackets the abbreviation of the biogeographic distribution known for each syntaxa.

MYRTEOLO NUMMULARIAE-SPHAGNETEA MAGELLANICI Oberd. 1960

Myrteolo-Sphagnetalia magellanici Oberd. 1960 [VP, Mag]

Astelio pumilae-Oreobolion obtusanguli Oberd. 1960 [VP, Mag]

Schoeno rhynchosporoides-Oreoboletum obtusanguli Oberd. 1960 [NVald]

Drosero uniflorae-Donatietum fascicularis Ramírez 1968 [NVald, SVald]

Astelio pumilae-Marsippospermetum philippi Ramírez 1968 [NVald]

Chusqueo montanae-Schoenetum antarctici Ramírez et al. 2014 [NVald]

Schoeno andini-Lepidothamnetum fonkii Ramírez et al. 2014 [SVald]

Donatio fascicularis-Schoenetum antarctici Amigo et al. ass. nova [Mag]

Caltho-Oreoboletum obtusanguli Oberd. 1960 [Mag]

Gaultherio-Sphagnion magellanici Oberd. 1960 [VP, Mag]

Gaultherio-Sphagnetum magellanici Oberd. 1960 [NVald]

Polytricho alpestris-Sphagnetum Oberd. 1960 [Mag]

Caltho appendiculatae-Sphagnetum Oberd. 1960 [Mag]

Nanodeo muscosae-Sphagnetum magellanici Amigo et al. ass. nova [Mag]

Abrotanello linearifoliae-Bolacion caespitosae Amigo et al. all. nova [Mag]

Senecio trifurcati-Bolacetum caespitosae Amigo et al. ass. nova [Mag]

Azorello selaginis-Bolacetum caespitosae Amigo et al. ass. nova [Mag] 